\title{
Tasarımın Diyalektiği: Diyalektik Kavrayıșla Tasarım Kavramına Dokunma Denemesi
}

\section{Dialectic of the Design: Experiment of Touching the Concept of the Design with Dialectic Comprehension}

\author{
Devrim BARAN ${ }^{(*)}$
}

Özet

Tasarım dolayımı olan temel toplumsal sorunların saptandiğ kavramın neyle uğraştı̆̆ ve neye hizmet ettiğinin öncelendiği eleştirel yaklaşım, içi tüketim çağrışımlarıyla dolu maddi üretimin niteliksiz bir aracı ve kapitalist sistemin önemli bir parçası gibi sunulan eğitim, düşün ve yazın hayatında eksikliğini hissettirmektedir. Illk sözünde; tasarımı "unsurlar, prensipler ve teknik sinırlılıklar» başlıkları altında parçalayıp bu parçaların neden-sonuç ilişkilerinin üretim ve satış raporları üzerinden değerlendirildiği düşüncelerin/ögretilerin yer aldiğ kitapların toplumdan, emek ve gereksinimden kopuk düşünceyle geliştirilen son sözünü merak eder miydiniz? Dolayısıla tasarım alanında kullanılacak diyalektik kavrayış, bize var oluş, düşünüs ve iletişim alışkanlıklarımızı şekillendiren tasarım çıktılarının son yılların en dönüşürücü araçları olduğu gerçeğinin dile getirilebilme şansını tanıyacaktır. Bu makaleyle, tasarım kavramının bask ve sömürü düzenini tekrar ve tekrar üreten, toplumsal ve sinifsal değerlerin nitelikli çöküşlerini görünür kılan, tüketim bağımlıllğg yaratan türlü yüzeyleri ve kavramsal uzamları kapsamında bir düşünce üretmek/ başlatmak hedeflenmiştir.

Anahtar Kelimeler: Tasarım Kavramı, Diyalektik, Soyut, Somut.

(*) Yrd. Doç. Dr. Üsküdar Üniversitesi, İletişim Fakültesi, Görsel İletişim Tasarımı Bölüm Başkanı. devrim.baran@uskudar.edu.tr/devrimbaran@gmail.com 


\section{Devrim BARAN}

\section{Abstract}

A critical approach, defining basic social problems that have design mediation, prioritizing what the concept deals with and what it serves to, seems to be missing in the education, thought and literature which are presented as a unqualified mean of material production full of consumption calls and an important part of capitalist system. While reading a book in which the introduction divides the design into "components, principles and technical limitations" chapters and analyzes causal relationships of these over production and sales reports; would you wonder about the closing that is developed disconnected from society, labor and desire? Therefore, a dialectic comprehension in design will provide us with the opportunity to express the fact that design outputs are the most transformative tools of today which shape our habits of existence, thinking and communication. This paper aims to start/produce thinking on the various superficies and

Üsküdar University Journal of Social Sciences Year:2 Issue:3 conceptual extensions of design which reproduces the exploitation and pressure system over and over again; makes the collapse of the social and class systems visible and creates consumption addiction.

Keywords: Design Concept, Dialectic, Intangible, Tangible.

\section{Giriș}

Raymond Williams'ın "Anahtar Sözcükler" seçiminde de haklı yerini alamayan tasarımı tanımlamak için kullanılan kavram, olgu, disiplin, eylem, emek, süreç, toplum, ürün, ortam vb. nitelemelerden acaba hangisinin anlamı en doğru olanıdır?

1 Sözcüklerin anlam tarihçeleri ve bu tarihçelerin kültür tarihi açısından ele alınarak kültür ve toplum başlığı altında gruplandırıldığı sözlükte, ele alınan 131 sözcüğün arasında tasarıma yer verilmemiş olmasının eleştirel göndermesi olarak düşünülmelidir. Raymond Williams, Anahtar Sözcükler, çev. Savaş Kılıç, (İstanbul: İletişim Yayınları 2007). 
$\mathrm{Bu}$ fenomen ${ }^{2}$ çeşitliliği, tasarım kelimesiyle dile getirilmeye çalışılan insan aktivitesinin ve anlam yapılarının bir sistem ${ }^{3}$ olarak düşünülmediği/ değerlendirilmediği sonucuna $\mathrm{m} 1$ işaret etmektedir? Doğada yalnızca insana ait olmadiğ $\iota^{4}$ bilinen bu özelliğin/aktivitenin gerçekle kurduğu ilişkinin oluşturduğu anlam basamakları, bir düşünce mi yoksa nesne (maddi) dolayımı olarak $\mathrm{m} 1$ değerlendirilmelidir? Toplumların ve teker teker insan aklının sessiz tanıklığında, tasarım kavramı üzerinden ışıldayan market rafları, mağaza vitrinleri ya da reklam/ekran görüntülerinin bireysel ve kitlesel etkileriyle gelişen ve içinde insanların yaşamlarını sürdürdüğü çevre, bilinçten bağımsız bir gerçek olarak mı değerlendirilmelidir yoksa bilinç o çevrede mi oluşmaktadır? Bu ve benzer soruların cevaplarına geçmeden önce tasarımın kültürel, ${ }^{5}$ ekonomik, teknolojik, toplumsal ya da yaratıcı etkinlik alanlarından oluşan çoklu yapısının eş zamanlı

2 Fenomen, duyular yoluyla algılanan tecrübe objesi. Diyalektik Materyalizm açısından, öz ile görünüş arasında aşılmaz bir sınır yoktur; özün anlaşılması fenomen aracılığıyla olur. M. Rosenthal, P. Yudin, Materyalist Felsefe Sözlüğ̈̈, çev. Aziz Çalışlar, (İstanbul: Sosyal Yayınları 1972), s. 162.

Fenomen sözünden doğa ya da toplum kanunlarının bütün tezahürleri anlaş1lır. Georges Politzer, Felsefenin Temel İlkeleri, çev. F. Karagözlü, (İstanbul: Sosyal Yayınları 1977), s.39.

Fenomen, nesnel gerçekteki eşyaları ve süreçleri yalnızca duyumlarla verilmiş olarak dile getiren felsefi kavramdır. Bir eşyanın, sürecin vb. fenomeni, henüz birbirlerinden ayrılmamış olarak duyum deneyimlerinde bulunan karakteristik olan ve olmayan özelliklerinin tümüdür. Oysa bunun karşıtı olan öz, eşyanın zorunlu, değişmez genel özelliklerinin toplamıdır. Fenomen ve öz, daima karşıtlıklardan meydana gelen diyalektik bir birlik kurarlar; fenomen, içinde özü barındırır, öz ise fenomenle dışsallaşır. Manfred Buhr, Alfred Kosing, Bilimsel Felsefe Sözlüğü, çev. Veysi Bildik, (İstanbul: Konuk Yayınları 1999), s.166.

3 Burada Münir Ramazan Aktolga'nın sistem tanımı kastedilmektedir: "Kendi aralarında bağlaşım (madde-enerji-haberleşme) halinde olup birbirlerinin varlık koşulu olan, etkileşerek, madde-enerjihaber alışverişinde bulunarak birbirlerini yaratan, birbirlerine göre (ilişkin-izafi) bir varlığa sahip olabilen, objektif-maddi gerçekliklerin meydana getirdiği bütüne sistem denir. Münir Ramazan Aktolga, Bilimsel Teknolojik Devrim ve Diyalektik, (İstanbul: Ulusal Kültür Yayınları 1991), s. 17.

4 "Hayvanların da aletleri vardır, ama yalnızca bedenlerindeki organlar olarak: karınca, arı, kunduz; hayvanlar da üretirler, ama onların çevrelerindeki doğa üzerindeki üretici etkisi doğaya göre hiç derecesindedir". Friedrich Engels, Doğanın Diyalektiği, çev. Arif Gelen, (Ankara: Sol Yayınları 1977), s. 51.

5 Makalede kullanılan "kültür” kavramı ile Troçki'nin tanımı üzerinden oluşan anlam yapısı düşünülmelidir. Buna göre: "Kültür denince, bakir ormanlar ve topraklardan farklı olarak işlenmiş bir tarla akla gelmez. Kültür ve tabiat birbirlerinin karşısında yer alırlar, yani insanın kendi çabasıyla değiştirip dönüş̧ürdüğü şey ile tabiatın verdiği şey birbirlerinin karşıtıdırlar. Bu anti tez geçerliliğini bugün bile koruyor”. Lev Troçki, Gündelik Hayatın Sorunları, çev. Yılmaz Öner, (İstanbul: Yazın Yayıncilik 2000), s. 255. 


\section{Devrim BARAN}

değerlendirilmesiyle tartı̧̧maya açılan bu metinin, "yolda geri geri yürüyen bir insanın arkasına bakarak ilerlemesini izlemek" gibi okunması önerilmektedir. Çünkü toplumsal, kültürel ve ekonomik bir sistem olarak ele alınmayan tasarımın, bütünlüğünü oluşturan belli parçaların sınırlı bilgisi üzerinden kavranmaya çalışılmasının imkânsızlığı, ${ }^{6}$ zaman zaman arkaya bakmayı gerektirmektedir.

Bireyi, yakın çevresini, içinde bulunduğu toplumu ve -çok iddialı görünse de- dünyayı nitel dönüşümlere sürükleyen tasarımın devrimci $\ddot{o} z \ddot{u},{ }^{7}$ ilkel komünal dönemden başlayarak günümüze kadar gözlemlenen toplumsal sınıf mücadelelerinin tam da içinde gizlidir. Dokunup görülebilen her şeyin üzerine bir hayalet gibi giydirilen ancak toplumsal ve kültürel dönüşümlerde üstlendiği aslan payına karşın kendi varlığının sorunsallarını tartışmaya açamayan (eleştirel düşünce eksikliği) tasarım, kavramlara ve

Üsküdar University Journal of

Social Sciences

Year:2

Issue:3

anlamlara şekil veren bir sonuç olarak insanla objenin yan yana geldiği her durumda varlığını hissettirmektedir. Dolayımları aracılı̆̆ıyla yol açtığı dönüşümlerin (nicel düzeyde) kesintisiz devamlılığına karşın, tasarlanmış

6 Bahsedilen imkânsızlık ile anlatılmak istenen, Ranciere'in tasarımı pratikler ve fikirler üzerinden dillendirdiği tanımlamalarından daha açık okunma imkanı sağlayacaktır: "(...) çizgiler çizilirken, sözcükler kullanılırken ya da yüzeyler bölmelenirken, ortak mekanın paylaşımlarının taslağl da çiziktirilir; (...) sözcüklerin ya da formların bir araya getirilmesiyle görülürün ve düşünülebilirin kimi konfigürasyonları, duyulur dünyada yaşamın kimi formları tanımlanır; (...) yirminci yüzyılın başında geliştiği biçimiyle tasarım pratiği ve fikri, paylaşılmış duyulur dünyayı konfigüre eden pratikler içinde -meta yaratıcılarının, metaları vitrinlere ya da görüntülerini kataloglara koyanların, "kentsel döşeme" yi inşa eden bina ya da afiş yapımcılarının, ama aynı zamanda kimi kurumlar çevresinde yeni ortaklık biçimleri öneren politikalar (...)" Zizek'in deyimimle "yamuk bakmayı" gerektirmektedir. Jacques Ranciere, Görüntülerin Yazgısı, çev. Aziz Ufuk Kılıç, (İstanbul: Versus Yayınları 2008), s. 95. 7 "Binlerce yıllık savaşımdan sonra, el, ayaktan ayrıldl, sonunda dik yürüyüşs sağlandl, (...) heceli konuşmanın gelişmesi ve beynin büyük gelişmesi için temel atıld (...) Elin uzmanlaşması alet demektir, alet de özgül insan faaliyeti, insanın doğa üzerindeki dönüştürücü tepkisi; üretim demektir. (...) Insan bitkilerin ve hayvanların yerini değiştirmekle kalmayıp, oturduğu yerin görünüşünü, iklimini, hatta bitkileri ve hayvanları, faaliyetlerinin sonuçlarını ancak yeryuvarlağının tamamen yok olmasıyla ortadan silinebilecĕgi biçiminde değiştirerek, doğaya damgasını vurmayı başarmıştır. Her şeyden önce ve temelde, bunu elin yardımıyla başarmıştır. (...) Ama el ile birlikte adım adım beyin de gelişti. Aynı pratik yararlılıktaki faaliyetler gerekli koşulların bilinci doğdu, sonra da daha iyi durumdaki topluluklarda ve bu bilinçlilikten hareketle onlara egemen olan doğa yasalarını kavrayış gerçekleşti. (...) Insanın beyni, el ile birlikte ve onun yanında, kısmen onun sayesinde aynı şekilde gelişmeseydi, tek başına el, buharlı makineyi asla ortaya koyamazdı “. Friedrich Engels, Doğanın Diyalektiği, çev. Arif Gelen, (Ankara: Sol Yayınları 1977), ss. 51-52. 
Tasarımın Diyalektiği: Diyalektik Kavrayıșla Tasarım Kavramına Dokunma Denemesi

iletilerle uyuşturulan ve düşünme becerilerini yitiren toplumun konu edildiği tartışmalarda sıklıkla yer bulan ahlak, bilim, iletişim, endüstri ve tüketim gibi kavramların değişik düzlemlerde kesişmeleriyle oluşan denklemlerin eksik öğesi her zaman tasarımın kendisi olmuştur. Dolayısıyla, tasarıma ilişkin bütünlükçü bir konumlandırma yapılamamasının yarattığı çelişki ve gerilimin sebebi, felsefenin temel hareket noktası olan bilinç (öznel, tinsel olan) ile varlık (nesnel, maddesel olan) arasındaki somut bağdan kaynaklı "öznelin nesneyle (tinsel olanın maddesel olanla, bilincin nesnel dünyayla) olan ilişkisi" üzerine bu alanda yeterli düşüncenin üretilememesiyle açıklanabilir. İrfan Erdoğan, öznelin nesneyle olan ilişki sorusuna verilen yanıtlarla tüm felsefe okullarının iki kamptan birinin içine düştüğünü dile getirmektedir. Hareket noktası olarak bilinci temel alanlar idealist felsefeyi, doğayı yani madde ve somut olanı öne çıkaranlar ise materyalist felsefeyi oluşturmaktadır. Özü anlamada idealist felsefenin tin ve insan düşüncesini çıkış noktası yaptığ 1 yerde materyalist felsefe, düşünceden değil düşünen insandan yola çıkar. Var olan diş gerçeğin, düşünceden yani akıl ve dilden geçerek şekillendiğini, insan dünyasının düşünceden başlayarak, düşünce odaklı yapılabileceğinin öncelendiği idealist felsefeye karşı materyalist felsefede ise nesnel gerçeğin insan aklından ve düşüncesinden bağımsız olarak bulunduğu, düşüncenin gerçeği belirlemediği öne çıkarılır. ${ }^{8}$

Lacan'ın ihtiyaç, talep ve arzu' arasında yaptığı ayrımla daha da ulaşılmaz görünen tasarım dilinin egemen öğreti sistematiği içinde değerlendirildiği,

8 İrfan Erdoğan, Pozitivist Metodoloji ve Ötesi, (Ankara: Erk Yayınları 2012), ss. 18-19.

9 “(...) Lacan' in ihtiyaç, talep ve arzu arasında yaptığı ayrımı; yani, ihtiyaçlarımızdan birini karşılaması beklenen sıradan bir nesnenin, talep diyalektiğine yakalanır yakalanmaz bir tür dönüşümden geçip arzu üretir hale gelmesini örneklerler. Birinden bir nesne talep ettiğimizde, o nesnenin "kullanım değeri" (bazı ihtiyaçlarımızı karşılamaya hizmet ediyor olması) eo ipso, "değişim değeri" ni ifade etmenin bir biçimi haline gelir; söz konusu nesne, özneler arası ilişkiler ağının bir göstergesi işlevini görür. Talepte bulunduğumuz kişi isteğimize uyduğunda bize karşı belli bir tavır sergilemiş olur. Demek ki belli bir nesneyi talep etmemizin nihai amacı, o nesneye bağlı bir ihtiyacı karşılamak değil, ötekinin bize karşı tavrını onaylamaktır. Mesela bir anne çocuğuna süt verdiğinde süt sevgisinin bir nişanesi olur. Zavallı Midas, ele geçirdiği her nesne "kullanım değeri" ni yitirip "değişim değeri" nin saf, işe yaramaz cisimleşmesine dönüştügüunde, tamahkârllğının ("değişim değeri"nin peşinde koşmasinin) bedelini ödemektedir: Isırdığl yiyecek, anında altına dönmektedir”. Slavoj Zizek, Yamuk Bakmak, çev. Tuncay Birkan, (İstanbul: Metis Yayınları 2012), ss. 17-18. 


\section{Devrim BARAN}

varlığının insan düşüncesi üzerinden konumlandırıldığı idealist düşünce sisteminin, ${ }^{10}$ tasarım nesnesinin somut bir varlık olarak düşünüldügü ve gerçeğin dönüşen insanın bilincinden dışarıda aranması gerektiğinin öne sürüldügü materyalistlere göre sesinin daha yüksek tondan çıtığı bilinen bir gerçektir. Çünkü tasarım kavramı için geliştirilmeyen eleştirel düşüncenin gölgesinde kalan diyalektik kavrayış, form-anlam-statü üzerinden yaratılan yükselen değerlerin bu alandaki yararcılığına hapsedilmektedir.

Marx'ın Hegel'den teslim alarak diyalektiği getirdiği noktada tasarımın yapısal açılımlarına katacağı zenginlik, eğer izin verilseydi, dünya savaşlarıyla başlayan 1900'lü yıllarda birer tasarım ürünü olan ateşli silahlar ya da bombalar yüzünden hayatlarını yitiren milyonlarca insan ile geride kalanlardan oluşan nüfusun içinde bulunduğu olumsuz durumu anlatmak

Üsküdar University Journal of Social Sciences Year:2 Issue:3 için kullanılacak "kurşun zehirlenmesi" metaforunu, silahtan çıkan kurşunun ölümcül gücü ya da "kurşun harflerin" 11 taşıdığı kirli propaganda üzerinden seslendirebilecekti. Eleştirel ve bilimsel düşüncenin eksikliğiyle (tasarım varlığının, varlık sebebi olan insanın bilincini oluşturduğu, yönettiği ve yönlendirdiği) oluşan boşluğun tüketimi ve sömürüyü yücelten

10 İdealist düşünce sistemiyle genellemeye çalışılan durum; tasarlanan bir nesnenin insan düşüncesiyle oluştuğunun öne sürüldüğ̈̈ her zeminde o nesnenin oluşmasını sağlayan insan düşüncesinin de içinde bulunduğu çevrenin bir ürünü olduğu gerçeğinin göz ardı edildiği etkinlik alanlarını kapsamaktadır. İdealist yaklaşımla yorumlanan tasarlanmış bir kullanım nesnesi, onu tasarlayan tasarımcı, o tasarımı isteyen üretici ve o tasarımı kullanan tüketicinin oluşturduğu sacayağından oluşur. Bu sacayağını oluşturan kesimlerin düşünceleri ile sınırlanan etkinlik alanı, tasarım kavramını taşıyamayacak kadar küçüktür. Çünkü yüzyıllar içinde gelişen ve biriken insan pratiğinin bulunduğu zaman dilimindeki adı örneğin "masa" olabilir ancak tasarım kavramı, bu isimin altında bulunan kullanım değeri, hangi amaca yönelik geliştiği, çevresel koşulların yarattığı ergonomi (kullanım kolaylığı), sınıfsal göstergeler, duygusal çağrışımların vb.nin bütünü ile oluşur. Bu kapsamla ele alınan kavramın görünen haline yani masaya dokunurken, aslında tasarım somut bir kavrama dönüşmektedir. Dolayısıyla ne tasarımcının ortaya koyduğu ürünü oluştururken çevresinden soyutlandığı, ne üreticinin böyle bir ürünün eksikliğini duyumsarken yalnız olduğu ne de tüketicinin ilk defa masayla karşılaştığı söylenemez.

11 Yüksek baskı sistemine uygun olarak hazırlanan klişelerinden baskı elde etmeye yarayan alet ve makinelerin tümünde, dizgi işlemi için $\% 70$ oranında kurşundan oluşan metal harfler, hurufat anlaşılmalıdır. Mustafa Kınık, Grafik Tasarım ve Üretim Teknolojileri, (Ankara: Asil Yayıncılık 2005), s. 101. 
egemen söylem ${ }^{12}$ tarafından doldurulduğu günümüz dünyasında; tasarım kavramının, ne savaşı ve tüm vahşetiyle kitlesel katliamları sıradanlaştırarak televizyon ekranına sı̆̆dırdığını, ${ }^{13}$ açıkça ölüme çağırdı̆̆ını, ${ }^{14}$ kandırıp kontrol eden ideolojilerin en yaratıcı araçlarından biri halini aldığını, ne de toplumları yalnızlaştıran ve yersiz yurtsuz bir tüketim öznesine dönüştüren kapitalist ekonomik sistemde kendi dolayımlarıyla makineleştirdiği, köleleştirdiği ve gerçek olmayan bir dünyaya hapsettiğini duyabilmek pek olanaklı durmamaktadır.

İçinde gelecek kurguları yapılırken nefes almanın başarılabildiği her köşede yaşam, "şu ya da bu şekilde tasarlanmış sonuçlar tarafindan bütünüyle koşullanmış"15 haliyle devam ediyor. Tasarlanan sonuçların yani tasarım varlığının "istemli ya da istemsiz, amaçlı ya da amaçsız bir iletişim ortamı hazırladiğı, tasarımcı ya da kullanıcının ürünler üzerinden çevreye, kendilerine iliş̧kin bilgi gönderdiği veya tersi bir işlemle çevreleri tarafindan bir anlamlamanın konusu olarak ele alındiğı" ${ }^{\prime 16}$ noktada güç

12 Marx ve Engels Alman İdeolojisi'nde egemen düşünceyi şöyle açıklamışlardır: "Egemen sinıfin düşünceleri, bütün çağlarda egemen düşüncelerdir, başka bir deyişle, toplumun egemen maddi gücü olan sınıf, aynı zamanda egemen zihinsel güçtür. Maddi üretim araçlarını elinde bulunduran sınıf, aynı zamanda zihinsel üretim araçlarını da emrinde bulundurur, bunlar o kadar birbirinin içine girmiş durumdalardır ki, kendilerine zihinsel üretim araçları verilmeyenlerin düşünceleri de aynı zamanda bu egemen sinıfa bağımlıdır. (...) egemen düşünceler, fikir biçiminde kavranan maddi, egemen ilişkilerdir". Marx ve Engels, Alman İdeolojisi [Feuerbach], çev. Sevim Belli, (Ankara: Sol Yayınları 2010), s. 75. Dolayısıyla "egemen söylem" ile metinde; egemen sınıfın dolayımıyla oluşan ekonomi, sosyal yaşam, politika gibi sosyal fenomenlerin birbirinden soyutlandığı ve farklı alanlar olarak tekrar yaratıldığı mecraların çıktıları anlatılmak istenmiştir. Örneğin bu parçalanan ve birbirinden soyutlanan alanlar haber bültenleri ve günlük gazetelerin akışlarında da karşımıza çıkar. Uzun yıllardır böyle yapıldı̆̆ için herkese normal gelmesine karşın ekonomi ve politika sayfalarının içeriklerinin birbirinden olabildiğince ayrı tasarlanması, bahsedilen soyutlamayı yani algı parçalanmalarına en yalın örneklerden birisidir. Egemen söylemin sesinin en yüksek çıktığı ana akım medya ya da "yararcılık" refleksiyle kurulan üniversite-sanayi işbirliklerinin bilgi üretmeyi ötelediği ana akım akademi ve yayınları aracıllı̆̆ıla birbirinden soyutlanan bu alanlar, ayrıca kendi içinde de yüzlerce popüler bölüme ayırırlar.

13 Körfez savaşında kullanılan füzelerin TV ekranlarından tüm dünyaya servis edilmesi halen hatırlanmaktadır.

14 "I Want You" Seni İstiyorum Afişi, II. Dünya Savaşında Amerikalıları savaşa davet etmek için 5 milyon adet basılmıştır.

15 John Heskett, Tasarım, (Ankara: Dost Yayınları 2013), s. 15.

16 Oğuz Bayrakçı, Çağdaş İletişim Kuramları Açısından Tasarımda İletişimsel Modeller, (İstanbul: Mimar Sinan Güzel Sanatlar Üniversitesi Yayınları 2004), s. 15. 


\section{Devrim BARAN}

kazanan tasarım kavramı, ancak diyalektik bir kavrayışla "dokunulabilen" maddi varlığa dönüşebilir.

Malcolm Barnard'in dile getirişiyle "insan görsel desenlere, şekillere, dokulara ya da ritimlere tepki verir", ${ }^{17}$ yani bu unsurların teker teker ya da aynı anda yan yana gelmesiyle oluşan el ürünü nesne ya da endüstriyel metalar üzerinden oluşan bilincin (madde bilinci oluşturur) ham maddesinde ağırlıklı olarak bulunan farklı şekil, desen ya da dokuya sahip tasarım ürünleri "nesnel gerçeğin, merkezi sinir sistemi aracıliğıyla oluşan bir yansıması"18 şeklinde yaşamlarımıza katılmaktadırlar. Dolayısıyla duyu organlarının çevreyle kurduğu etkileşimin sonucu olarak toplanan bilginin (tepkinin), sinir sisteminde bir bölgeden başka bir bölgeye aktarılan maddi süreciyle oluşan duyumsama, gerçek olan ile simgesel olan arasındaki travmatik ilişkinin doğru yönetilemediği ve bilinç kayıplarının oluştuğu bir zeminde

Üsküdar University Journal of Social Sciences

Year:2

Issue:3 gerçekleşir. Yani "beyin, toplumsal pratikten edinilen bilgi temelinde, imgeleri insanın bireysel ve toplumsal deneyimlerine uygun olarak düzenler. Dolayısıyla, bilginin duyumlar temelinde ortaya çıkmasına karşın, duyumlar daha önceden edinilen ve pratik tarafindan doğrulanan bilginin etkisi altında oluşur". ${ }^{19}$ Karşıt ve birbiri içinde bulunan sınıfsal ilişkilerin özü olan toplumsal pratik, toplumun farklı katmanlarında eş zamanlı gelişen ve büyük oranda görsel duyumsamayla oluşan bir deneyimdir. $\mathrm{Bu}$ nedenle yaşamın birçok alanına sızdığı ve kullanılma amacını kesintisiz sürdürmeye devam ettiğinin göz ardı edilmemesi gereken tasarım kavramı, egemen düşünceyi üreten ve yayan ana akım akademinin ${ }^{20}$ himayesinde

17 Malcolm Barnard, Sanat, Tasarım ve Görsel Kültür, (Ankara: Ütopya Yayınları 2002), s.143.

18 Manfred Buhr, Alfred Kosing, Bilimsel Felsefe Sözlüğ̈̈, çev. Veysi Bildik, (İstanbul: Konuk Yayınları 1999), s. 403.

19 Boguslavsky/Karpuşin/Ratikov/Çertikin/Ezrin, Diyalektik ve Tarihsel Materyalizmin Alfabesi, çev. Şiar Yalçın, (Ankara: Bilim ve Sosyalizm Yayınları 1990), s. 179.

20 Marx ve Engels'den yola çıkarak; maddi üretim araçlarını elinde bulunduran sınıf, aynı zamanda zihinsel üretim araçlarını da, örneğin kendi sahipliği ve girişimiyle kurduğu ya da desteklediği üniversiteleri de emrinde bulundurmak isteyeceğini önceleyen bir kavramsallaştırmadır. Bu kavramsallaştırma denemesiyle öncelenmek istenilen duygu Nazife Güngör'ün şu saptamasında da dile getirilmiştir: “(...) Toplumda gücü elinde bulunduran kesimler insanllk tarihinin her döneminde bilgi üretim ve dağıtım alanlarını kendi yetki ve etki alanları içerisinde tutmaya önem vermişlerdir". Nazife Güngör, İletişim, Kuramlar-Yaklaşımlar, (Ankara: Siyasal Kitabevi 2011), s. 117. 
bir mutluluk kaynağı olarak öğretilir: O tasarım nesnesini üreten ve satan kapitalist sistem, nasıl tasarlanacağını ve pazarlanacağını gösteren eğitim sistemi, vadedilene inanmaktan ve tüketmekten başka şansı olmayan toplumun duyumsadığı mutluluğun, özde sahip olma güdüsünden başka bir şey olmadığının (Erdoğan'ın ${ }^{21}$ ifadesiyle düşünseli, bilinci ve özneli materyalin ürünü olarak gören diyalektiğin sunabileceği) çoklu kavrayış ve ilişkilendirme yapılarak anlaşılabileceği ortadadır.

\section{“Marxçı Yöntemle”22 Tasarımı Kavramsallaștırmak: Soyut mu Somut mu?}

"Bir kavramın “dünyayı kapsaması” için, o kavramın zahmetle meydana
getirilmiş, üzerinde uğraşılmış, esnek, müteharrik, izafi, karşılıklı bağlılık
içinde olması gerekir." 23

21 İrfan Erdoğan, Pozitivist Metodoloji ve Ötesi, (Ankara: Erk Yayınları 2012), s. 20.

22 İrfan Erdoğan bu analiz şeklini şöyle tanımlamaktadır: "Marxçı analiz Marx’ı̀ tarihsel materyalizm yaklaşımından hareket ederek yapılan, düşünsel veya maddi hayatın üretimiyle ilgili konularl/sorunları ele alan analizdir. (...) Marxçı ve Marx tan esinlenen yaklaşımlar, veri toplama ve değerlendirme bağlamında niteliksel analizlerdir. (...) Marx' 'n Materyalist yöntemi, insanın kendi yaşamını örgütleme ve tarihini yapma biçimidir; yani Marx'ın insan, toplum ve tarih anlayışıdır. Bu anlaylş insanın kendi tarihini kendi içinde bulunduğu koşullarda yaptığını belirterek insanı merkeze koyar; düşünceyi, devleti veya şirketi değil. İnsan aynı zamanda hem materyal hayatın hem de düşünsel, duygusal ve inançsal hayatını üretir. Dolaylsılla düşünceler, tarih, dil, diskors ve ideoloji insandan bağımsız, insanın dişında, "şeyleri ve insanı biçimlendiren" aktif aktörler değildir; tarihi, dili, diskorsu ve ideolojiyi yapan insandır ve bu insan dili, diskorsu ve ideolojiyi kullanarak sadece kendini ifade etmez, aynı zamanda kendini biçimlendirir. (...) Marxçı bir araştırmada, dilin, diskorsun veya ideolojinin insanı ve yaşamı belirlediği anlayışı, idealist felsefe içine düş̧ü̆gü için yanlış olarak nitelendirilir. Bunun anlamı, idealist felsefe içine düşsen analizlerde (örneğin post-yapısalcı ve kültürel çalışmalar incelemelerinde) sunulan her şeyin yanlış olduğu değildir. İdeolojik ve kültürel pratiklerle oluşturulan ve sürdürülen, örneğin tüketim toplumu, akılsızca tüketim, gerçeğin üzerine imajların çökertilerek yaratılan duygusal ya da düşünsel ortam gibi açıklamalara yanlış denilemez. Yanlıs olan, özellikle, toplumu, insanı, gerçeği ve insan yaşamın belirleyenin dil olmasl, binlerce ylldır sürdürülen "teolojik yaradlllş" teorisinin yerini "aklın, dilin, diskorsun" (bir bașka soyut birimin) almasıdır. Dil ve ideoloji hiçbir şey yapamaz, çünkü yapabilen canlı aktörler değildirler. Yapan aktör, diliyle, düsüncesiyle ve ideolojisiyle kendini ve diğerlerini biçimlendiren, diğerleri tarafindan biçimlenen insandır. Örnek olarak, sigara insanı öldüremez, eğer sigara üretilemez ve içilmezse. Marx "sigara öldürür" söylemindeki düşünceyi (ideolojiyi) kabul eder, ama "öldürme işini” düşünceyle veya son ürünle ilgili faaliyetle (sigara içmeyle) sinırlamaz; "öldürme işini”" sigaranın üretiminden kullanımına kadar olan ve sigaranın da üretildiği tarihsel üretim ilişskileri içinde ele alır. Bu mu indirgemecilik yoksa "sigara öldürür" deyip sigarayl (ve sigara içeni) suçlamak mı?" İrfan Erdoğan, Pozitivist Metodoloji ve Ötesi, (Ankara: Erk Yayınları 2012), ss. 135-137.

23 Lenin, Toplu Eserleri, cilt 38, s.14. 


\section{Devrim BARAN}

Çalışmanın giriş kısmında tasarım kelimesiyle ilgili oldukça fazla fenomen kullanıldığından bahsedilmişti. Bu karışıklığın sebebi olarak, tasarım kavramına sıradan kalem ve kâğıt gibi somut ya da özgürlük ve inanç gibi soyut olarak ele alınan klasik kavram tanımlamalarının estetize edilmeye çalışılmasıyla oluşan kargaşa gösterilebilir. Çünkü tasarım "çeşitli özellikleri ve bağlamlılıklarıyla birlikte ele alınan eşyaların, bir bütünlük ortaya koyan duyumsal imgesidir; ancak algldan farklı olarak, tasarım, belirli bir anda duyu organlarına etki yapan eşyaların o anda ve doğrudan doğruya beliren bir imgesi olmayıp, daha önce algılanmış olan eşyanın yeniden üretilen algısal imgesi" ${ }^{24}$ olarak değerlendirildiğinde, soyut ve somut algılayış yer değiştirmekte, birbirinin içine girmektedir. $\mathrm{Bu}$ alıntının "daha önce algılanmış olan eşyanın yeniden üretilen algısal imgesi" kısmı, dikkatle değerlendirilmesi gereken önemli bir genellemedir;

Üsküdar University Journal of Social Sciences Year:2 Issue:3 çünkü "yeniden üretilen algısal imge", bize tasarımı kavramsallaştırma şansı tanıyan önemli bir çıkış noktasıdır.

Yeniden üretilen algısal imge olarak bir tasarım varlığı, insanın "an'ın gerçeğinden kopmasına, geçmişi yeniden kurmasına ve geleceği tahmin etmesine, fikirselleşmiş eşyalar ve düşsel ürünler meydana getirmesine"25 zemin hazırladığ önemli yeri bulunmaktadır; keza düş gücünün de bu kaynaklardan beslendiği söylenebilir. Dolayısıyla tasarımı kavramsallaştırma çabası, bu öngörülerle belirlenen ve farklı düzlemleri kapsayan bir çalışma alanına sahip olmak zorundadir.

Klasik anlamıyla kavramlar, gözlem, duygu ya da düşünceyi anlatan zihinsel çağrışım, dünyanın zihinde yansımasının formlarından biri, bilmenin alt safhasından daha üst safhaya gidişin yani bilmenin tarihi gelişmesinin ürünü, pratik ya da bilgi bakımından bizi ilgilendiren objelerin belirli vasıflarını düşüncede ayırt edebilmek şekli, kelimeler ile belirli

24 Manfred Buhr, Alfred Kosing, Bilimsel Felsefe Sözlüğ̈̈, çev. Veysi Bildik, (İstanbul: Konuk Yayınları 1999), s. 403.

25 Manfred Buhr, Alfred Kosing, a.g.e., s. 403. 
Tasarımın Diyalektiği: Diyalektik Kavrayıșla Tasarım Kavramına Dokunma Denemesi

objeler arasında bağ kuran, düşüncede bu kelimelere işlevsellik kazandıran yapilardir. ${ }^{26}$

Maddi genellemelerin yanı sıra görüp dokunamadığımız düşünsel soyutlamalar olarak da karşımıza çıkabilen, örneğin elle dokunulamayan bir eşya olsa da ne olduğu, nasıl hissedildiği ya da anlaşıldığı özgürlük gibi somut ve gözlemlenebilir durumlara ilişkin fenomenlerin zihin tarafından bilindiği bir kavrayıştır; tıpkı ideoloji ya da hegemonya gibi. Ek olarak bu klasik yaklaşımlarda, kavramların maddi nesneler için genelleme üzerine temellendirilen bir soyutlama olduğu da dile getirilmektedir. Örneğin meyve kavramı için özellikli bir meyve yerine birçok meyve niteliğindeki sebze genelleştirilerek soyutlanmıştır. ${ }^{27}$

Bir dilin kelimelerine anlam katan, "Gerçeğin özünü dile getiren, somut gerçekliğin çeşitli belirlenimlerini içeren teorik üretiş"28 (görünümden öze) olarak düşünülen kavramlar Lenin'in dile getirdiği şekliyle, maddenin en yüksek formu olan beynin en yüksek ürünüdürler. En temel ve genel özelliklerini kendisinde taşıyan nesnel bir ilişkiyi, gerçekliğin cansız, hareket ve değişimlerden arındırılmış halini dile getirirler; duyumlardan başlayarak pratiğin tekrarlanmasılyla meydana gelirler (nicelden nitele). ${ }^{29}$ Mao Tse-Tung ${ }^{30}$ kavramı şöyle tanımlamıştır: "Sosyal pratiğin devam etmesi insanlarda duyum ve kavraylşlar meydana getiren fenomenlerin birçok defa tekrarlanmasina yol açar. O zaman insan bilincindeki bilgi sürecinde bir sıçrama olur: kavramlar ortaya çıkar". Bahsedilen sosyal pratik içindeki duyum ve kavrayışların oluşturduğu fenomenlerin insan zihninde yarattığ1 sıçramaların, böyle düşünüldüğünde fikirselleşmiş eşyalar ve düşsel ürünler üzerinden yani tasarım nesneleri dolayımıyla sağlandığ 1 gayet açıktır.

26 M. Rosenthal, P. Yudin, Materyalist Felsefe Sözlügü̈, çev. Aziz Çalışlar, (İstanbul: Sosyal Yayınları 1977), s. 259.

27 Maurice Bouvier-Ajam, Jean İbarrola, Nicolas Pasquarelli, Marksist Ekonomi Sözlüğü, çev. B. Aren, (İstanbul: Sosyal Yayınları 1977), İ. Yaşar, s.288.

28 Maurice Bouvier-Ajam, Jean İbarrola, Nicolas Pasquarelli, a.g.e., s.288.

29 Georges Politzer, Felsefenin Temel İlkeleri, çev. F. Karagözlü, (İstanbul: Sosyal Yayınları 1977), s. 66.

30 Mao Tse-Tung, Çin İnkılâbının Teorik Meseleleri, çev. K. Sahir Sel, (İstanbul: Sosyal Yayınları 1966), s.14. 


\section{Devrim BARAN}

Buraya kadar somut ve soyut olarak ayrılan kavramlar Marxçı analizde, günlük dildeki kullanımlarından farklılaşmaktadır. Çünkü Marx, araştırma yöntemi olarak somuttan soyuta yönelişi bilimsel bulmamış, kitap ve makalelerinde doğru yöntem olarak soyuttan somuta yönelişi yani somutlamayı işaret etmiştir. Mehmet İnanç Turan ${ }^{31}$ Marx'ın somut ve soyutunu şöyle açıklamaktadır: "Somut, dış dünyadaki nesnel gerçekliğin bilgisidir. Soyut, somutun yansımasıyla düşünce alanında oluşan parçaların bilgisidir. Somut, soyut parçaların bileşimini kendinde toplar. Söz gelimi burjuva toplumu ekonomik yapısiyla maddi bir somutu dile getirir. Bu toplumun düşüncede soyutlanmış parçaları (para, mübadele, artı-değer, ücretli emek, meta vb. ekonomik kategoriler) sinırl bilgileri ifade eder". Buna göre tasarım maddi bir somutu dile getirirken düşüncede soyutlanan sınırlı bilgi kaynaklarını ise ürün, teknoloji, yaratım, üretim vb. basamaklar/ parçalar oluşturmaktadır. Yani somut olanı zihinde yeniden elde ederek

Üsküdar University Journal of Social Sciences Year:2 Issue:3 nesnel gerçekliğin bilgisine ulaşmak olan soyuttan (her bir parçadan) yola çıkış, somutun düşünsel düzlemde var edilmesinden başka bir şey değildir. Burada soyut; belirlenimsiz, bağlantısız, kendinde ve kendiliğinden, hareket ve değişim hakkında ön bilginin olmadığ ilk algılanış/görünüştür: "Soyuttan somuta yükselme yöntemi, düşünce için sadece somutu kendine mal etmenin, onu zihinde somut olarak yeniden üretmenin yoludur". ${ }^{32}$ Marx somut kavramını ise şöyle tanımlamaktadır: "Somut, çok sayıda belirlemenin bir noktada bağdaşması, dolayısıyla çoğulluğun birliği olduğu için somuttur. O halde somut, gerçek hareket noktası ve dolaylsiyla gözlem ve tasavvurun da gözlem noktası olduğu halde, düşüncede bir hareket noktası olarak değil, bir toplama ve birleştirme süreci, bir sonuç olarak ortaya çıkacaktır". ${ }^{33}$ Tasarım birçok belirleyenin ortak noktada buluşması ve birliği ile oluşan bir sonuçtur; hem de somut bir sonuç. Dolayısıyla, bir kavramın (özellikle tasarım kavramının) soyut mu somut mu olduğuna, onun işaret ettiği varlığın klasik anlamıyla soyutluğu

31 Mehmet İnanç Turan, Marx’ın Grundrisse ssi, (Ankara: Ütopya Yayınevi 2015), s. 17. 32 Marx, Grundrisse, çev. Sevan Nişanyan, (İstanbul: Birikim Yayınları 1979), s. 168.

33 Marx, Grundrisse, a.g.e., s. 169. 
Tasarımın Diyalektiği: Diyalektik Kavrayıșla Tasarım Kavramına Dokunma Denemesi

ya da somutluğuyla değil, kavramın düşüncede ilerleme sürecinin neresinde olduğuyla karar verilmelidir. ${ }^{34}$

Materyalist diyalektiğin anlaşılır kıldığ kapsayan bilimsel tasarım kavramı, duyusal edimlerle hissedilebilen eldeki nesnel gerçeğin ifadesinden öte bu nesnelliği oluşturan soyut parçaların somutlaştırdığ1 fikirsel eşyaları ve düşsel ürünleri görünüşten öze tanımlanabilir hale getirmektir; aslında olan şey "daha önce algılanmış olan eşyanın yeniden üretilen algısal imgesi" yani bilinci oluşturan maddesel çağrışımların çözümlenmesi sürecidir. Sıradan bir günde dahi yaşam binlerce farklı tasarım ürünüyle paylaşılmaktadır. Diyalektik, market rafları, otomobiller, iletişim mecraları, ayakkabılarınız, yani kurtulmanın mümkün olmadığı bu doluluğun hangi emek, ilişki biçimleri ve sınıfsal çatışmaların içinde oluştuğunu, bu çelişkilerin sonucu olarak beliren form ve estetik değerler ile satın alınma süreci gibi düşüncede soyut parçaları tanımlarken tasarım kavramının somut değişkenliğine de işaret etmektedir ("somut değişkenlik" ile diyalektiğin önemli özellikleri arasında bulunan bütün şeyler birbirine bağlldır, gerçek bir bütündür, gerçek hareket ve süreçtir, her şey zaman ve mekân şartları içinde gelişir gibi özlere dikkat çekilmek istenmiştir). Gelinen noktada tasarımın sandalye ya da kalem gibi dokunulamayan ${ }^{35}$ düşünsel yapısıyla toplumların gelişim süreçlerinde onları bir hayalet gibi takip eden özünü bulmak için herhangi bir tasarım varlığ çıkış noktası (ilk görünen öğe) olarak belirlendiğinde, bağımlılık yaratan

34 Aydın Çubukçu, Teoride ve Eylemde Diyalektik Materyalizm, (İstanbul: Evrensel Basım Yayın 2008), ss. 26-28.

35 Tasarıma dokunamazsınız, tıpkı topluma dokunamadı̆̆ınız gibi. Çünkü tasarım dolayımıyla şekillenen varlığın/maddenin/nesnenin adı tasarım değil kalem ya da sandalyedir. Şöyle ki: "Tasarım, nesnel gerçekliğe sahip olan bir eşya ile doğrudan doğruya iliş̧kili bulunmadığından, önemsiz özelliklerin dikkate alınmaması ve önemli özelliklere ağırlık verilmesi yoluyla belirli bir genelleştirmenin yapılmasina olanak verir. Duyumsal olan bu genelleștirme, tasarımı, algı ila kavram arasındaki bir bağlama halkası durumuna sokar. Insanın tasarımları, tıpkı algıları gibi, düşünme ve konuşma ile sıkı bir bağlantı içindedir. Söz konusu tasarımlar, daima, yansıyan eşyayı tanımlayan sözcüğ̈̈ içerirler ve tersine düşünce durmaksızın duyusal tasartm malzemesine göre yol alır; duyumsal bilgi ile rasyonel bilgi karşıllkll olarak birbirlerine geçerler”. Manfred Buhr, Alfred Kosing, Bilimsel Felsefe Sözlügü̈, çev. Veysi Bildik, (İstanbul: Konuk Yayınları 1999), s. 403. 


\section{Devrim BARAN}

yaratan bir meta ${ }^{36}$ yığını ile karşılaşmak sürpriz olmayacaktır. Yani değişik görünümlerde bulunan tasarım ürünlerinin üzerinde dolaşan hayalet; ilişkiler, üretim, ihtiyaç, iletişim, yaratım ve kullanım değeri gibi soyut parçalar üzerinden metaya (bütüne) dönüştükçe tasarımı bir kavram olarak içselleştirmenin güçlügü daha da anlaşılır olacaktır. $O$ halde diyalektik kavrayış, tıpkı burjuva toplumu gibi tasarımı da somut bir kavram olarak birçok soyut parçanın oluşturduğu büyük bir bütüne (somuta) taşımaktadır.

\section{Diyalektik Kavrayıșla Tasarımı Anlama Pratiği}

Üsküdar University Journal of

Social Sciences

Year:2

Issue:3

Bir önceki başlıkta da bahsedildiği gibi, yaygın kabullerin sonucu olarak gelişen kavramların taşıdıkları anlam ve kapsama ilişkin yaptıkları genelleme ya da soyutlamalar, o düşüncenin ya da nesnenin anlaş1labilmesini sağlar. Tasarım alanında kavramsallaştırmalara çok sık rastlanamaması, üretilen bilgiyi ve bu bilginin niteliğini, yayılmasını ve gelişmesini kendi sistemi içinde izi sürülemez hale getirmektedir. Anlaşılması, uygulanması, yazılması ve de öğretilebilmesi için, tasarımın uygulanmış hali olan varlık ${ }^{37}$

36 Meta: "Bir yandan insanın herhangi bir ihtiyacını gideren, öbür yandan, dolaysız olarak tüketilmek için değil, mübadele edilmek için üretilen şey. İlk karakteristiği bağlamında meta, bireysel bir ürün değil, sosyal bir üründür; örneğin yiyecek ya da giyecekler ama bir resim tablosu için meta denilemez. Metanın ikinci karakteristiği olan mübadele için üretilmiş olmak, onu belli bir ekonomik kontekst içinde ticari biçime dönüştürür. Dolayısıyla metanın zorunlu olarak bir kullanım değerine ve bir mübadele değerine sahip olduğu, Marx'ın da altını çizdiği gibi kapitalist üretim tarzında, servetin elemanter biçimidir. (...) İnsan emeğinin ürünü, zorunlu olarak meta biçimine bürünmez. Ama ticari üretim geliştikçe bütün ekonomik kategoriler meta olarak tezahür etme eğilimi kazanırlar. Böylece, kapitalizm çerçevesinde, mahiyeti itibariyle mübadele için yaratılmamış olan işgücü bile bir meta halini alır. Bu dönüşüm, Marx'ın rehberliğiyle ve itiraz götürmez bir biçimde "insanlar arasındaki ilişkilerin, sosyal sınıflar arasındaki ilişkilerin, șeyler arasındaki ilişkiler biçimi altında tezahür ettiğini” ispatlamış olur". Maurice Bouvier-Ajam, Jean İbarrola, Nicolas Pasquarelli, Marksist Ekonomi Sözlüğ̈̈, çev. B. Aren, İ. Yaşar, (İstanbul: Sosyal Yayınları 1977), s. 360.

"Kapitalist üretim tarzının egemen olduğu toplumların zenginliği, muazzam bir meta birikimi olarak kendini gösterir, bunun birimi tek bir metadır. (...) Meta her şeyden önce, bizim dışımızda bir nesnedir ve taşıdığı özellikleriyle, şu ya da bu türden insan özelliklerini gideren bir şeydir. Bu gereksinimlerin niteliği, örneğin mideden, ister hayalden çıkmış olsun, bir şey değiştirmez". Karl Marx, Kapital, Birinci Cilt, çev. Alaattin Bilgili, (Ankara: Sol Yayınları 2004), s. 45.

37 Varlık, bilinçten bağımsız olarak var olan objektif dünyayı (maddeyi) ifade eden felsefi kavram. M. Rosenthal, P. Yudin, Materyalist Felsefe Sözlügü̈, çev. Aziz Çalışlar, (İstanbul: Sosyal Yayınları 1972), s. 487.

Varlık kavramını Marx ve Engels hep "nesnel gerçek" anlamında ve maddi varlığı belirtmek için kullanmışlardır. Manfred Buhr, Alfred Kosing, Bilimsel Felsefe Sözlüğ̈̈, çev. Veysi Bildik, (İstanbul: Konuk Yayınları 1999), s. 456. 
ve bu varlık üzerinden oluşturulan anlam kümelerinin, değişik katmanlarda kesişen ancak farklı düzlemlerde yer alan bütününe hâkim olmak, balkonundaki çiçeklerini düzenleyen ile eğitim alarak profesyonel yaşamda üreten iki farklı insanın tasarım parantezinde nasıl buluşabildiklerinin anlaşılabilmesi açısından kaçınılmaz bir başlangıçtır. Bir önceki başlıkta yapılmaya çalışıldığ gibi işe, farklı anlam yapılarıyla ${ }^{38}$ tanımlanmaya çalışılan tasarım kavramının düşünsel ve hizmet eden ${ }^{39}$ özelliğiyle, bilimin aksine, hem istek oluşturan hem de bu isteğe yönlendiren yordam ve işlevini kavramsal düzlemde belirleyerek başlamak kaçınılmaz bir adımdı. ${ }^{40}$ Çünkü tarihsel süreçte hangi şekliyle görünürse görünsün "bir anlam yaratma" etkinliği olan ve her kesişmenin başka anlam yapılarının haberciliğini üstlenen tasarım kavramı, "insanın açığa çıkmasını engelleyemediği güçlü

38 Değişik zaman dilimlerinde yapılan tasarım tanımlarından yola çıkarak onlarca farklı anlamla karşılaşmak mümkündür. Nigan Bayazıt'ın yaptığı derleme ile farklı yazarların yayınlarına taşıdıkları tanımlamalar şöyledir: Belirsizlikler karşısında, hatalarına büyük cezalar ödenen bir karar verme eylemi (Asimov, 1962). Bilimin, tekniğin ve hayal gücünün mühendislik tasarımında bir mekanik yapıyı, makineyi ya da maksimum ekonomi ve etkinlik ile belirli bir işlevi gerçekleştiren bir sistemin tanımında kullanılışıdır (Fielden, 1963). Fiziksel bir yapıya en uygun gelen fiziksel bileşenleri bulmak (Alexander, 1964). Mevcut olaylardan gelecekteki olanaklara hayali bir atlamadır (Page, 1964). Yapmak ya da meydana getirmek istediğimiz şeyi değerlendirme yapmadan ya da meydana getirmeden önce, sonucundan emin oluncaya kadar yaptığımız benzetim (Brooker, 1964). Yaratıcı bir eylem olup, daha önce var olmayan yeni ve kullanışlı bir şey yaratmayı kapsar (Reswic, 1965). Bir amaca yönelmiş problem çözme eylemi (Archer, 1965). Belirli şartlarda gerçek ihtiyaçların tümünün en uygun çözümüdür (Matchett, Briggs, 1966). İlgili ürünle tatmin etme durumudur (Gregory, 1966). Çok karmaşık bir inancın yapılma şekli (Jones, 1970). Yargılayıcı bir süreçten kaynaklanan düzen için bir plan (Bevlin, 1994). Tasarım, bir sorunun çözümü için bir plandır, bir ide'dir (Tunalı, 2002). Tasarım çeşitli aşamalarında amaçlara ulaşmak için verilen kararlardan oluşan problem belirleme ve problem çözme yaratıcı eylemi (Bayazıt, 2004). Tasarım her yerde görülür, ancak yine de görünmez, fark edilmez ve tanımsız olabilir (Lupton, 2010).

Nigan Bayazıt, Tasarımı Anlamak, (İstanbul: İdeal Kültür Yayıncılık 2008), ss. 174-175.

İsmail Tunal1, Tasarım Felsefesine Giriş, (İstanbul: Yapı Endüstri Merkezi Yayınları 2002), ss. 12-13.

Oğuz Bayrakçı, Tasarımda İletişimsel Modeller, (İstanbul: Mimar Sinan Güzel Sanatlar Üniversitesi,

Mimarlık Fakültesi Yayınları 2004), ss. 1-8.

39 İnsanların sosyal yaşamları ile kamusal alanı oluşturan ev, iş, sokak, dinlence, inanç, yolculuk, üretim-tüketim, eğitim anlarını kapsayan iletişim gücü yüksek, yönlendiren ya da öğreten tasarım varlığı kastedilmiştir.

40 "Bilim insanlara yapmak istedikleri şeyi nasll yapacaklarını bildirir ya da gösterir. Bilimsel yordam, insanlara şunu ya da bunu yapmayı istetmeye kalkmaz. Öylesi, daha çok sanat yordamının işlevidir."

J. D. Bernal, Materyalist Bilimler Tarihi, cilt 1, çev. Emre Marlalı, (İstanbul: Sosyal Yayınları 1976), s. 43. 


\section{Devrim BARAN}

bir özelliği” olarak saptandığında; tekerleği, yontulan taşları, oyulan tabak çanağ 1 , askeri teçhizatları, toplumsal hayatı ve onun siyasetini ya da hukukunu, sağlığını ve eğitimini, mühendisliği ve teknolojisini kapsayan çok geniş tarihsel, toplumsal ve sınıfsal derinliğe (somut bütüne) ulaşır. Öyle ki, yontma taş aletler ile ok ve yay gibi savunma araçlarının kullanıldığı avcı ilkel komünal dönemde, madeni aletleri kullanarak hayvancılık, tarım ve el zanaatlarının geliştiği köleci sistemde, demirin eritilerek işlendiği ve imalathanelerin açıldığ 1 feodal yapıyla içlerinin makinelerle doldurulduğu fabrikalar ve bilimsel tarım araçlarının varlık sergilediği kapitalist toplumlarda gelişimi itibariyle birer tasarım ürünü olan üretim araçları "üretimle ilgili olan insanlar tarafından geliştirilmiş, insanlardan bağımsız kalmamışlardır. Bunun sonucu, üretim aletlerinin değişmesiyle birlikte, üretim güçlerinin esas öğesi olan insanlar da değişmiş ve gelişmişlerdir; insanların üretim deneyimleri, çalışma alışkanlıkları ve üretim aletlerini

Üsküdar University Journal of Social Sciences Year:2 Issue:3 kullanma yetenekleri" ${ }^{41}$ aynı zamanda toplumsal gelişmenin temel gücünü, sosyal sistemin niteliği ve görünüşünü, insanların düşüncelerini ve reflekslerini (bilinçlerini) şekillendiren önemli tarihsel göstergelerdir ${ }^{42}$.

İsmail Tunal1 ${ }^{43}$ tasarımın "pratik yaşamdan teorik yaşamın en üst basamaklarına kadar uzanan bir kullanım alanına sahip" olduğunu "elimdeki kalem, kullanmakta olduğum bilgisayar, duvarda asılı olan tablo, bilimsel bir araştırma ve yazı yazdiğım masanın” kalem ya da masa objesi halini aldığı andan itibaren doğada kendi başına rastlanamayacak bir kategori içine girdiğini, yani bir tasarım nesnesine dönüştüğünü ifade

41 Josef Stalin, Diyalektik Materyalizm ve Tarihsel Materyalizm, (Ankara: Bilim ve Sosyalizm Yayınları 1989), çev. Zeynep Seyhan, s. 41.

42 Aslında hepsi birer tasarım nesnesi olan ve uzun zaman dilimlerinde biriktirilen deneyimin kuşaktan kuşağa aktarılmasıyla gelişen "belirli çağ ve yerin aletleri, kulübe temelleri ve diğer arkeolojik kalıntılar tek tek değil de bir bütün olarak ele alındığında, çok daha fazla bilgi sağlayabilir. Bu kalıntılar yalnızca ulaşılan teknik becerileri ve bilim düzeyini değil, aynı zamanda bunları kullanan insanların geçimlerini nasıl sağladıklarını, yani ekonomilerini de gösterir. Türümüzün çoğalmasını ve böylece de biyolojik başarısını sağlayan da bu ekonomidir. Bu açıdan incelendiğinde, arkeologların çağları, aşağ yukarı ekonomik düzeyleri de tanımlamış olur. Her bir "çağ»ın, on sekizinci yüzyılda oluşan "Endüstri Devrimi" ile klyaslanabilecek önem ve biçimde ve aynı etkide bir ekonomik devrimi vardır". Gordon Childe, Kendini Yaratan İnsan, çev. Filiz Ofluoğlu, (İstanbul: Varlık Yayınları 1996), ss. 32-33.

43 İsmail Tunalı, Tasarım Felsefesine Giriş, (İstanbul: Yapı-Endüstri Merkezi Yayınları 2002), s. 12. 
eder. Bu nedenle sanat ve tasarım tarihinde geçmişi on binlerce yıl öncesine dayandırılan tasarım kavramı, "insanlığın gelişim ve hayatını devam ettirebilme mücadelesi" ya da "sorun saptama / çözüm yaratma sistematiği”" gibi güçlü tanımlarla ifade edilmeye çalışılmıştır.

Victor Papanek ${ }^{44}$ herkesin tasarımcı kimliği taşıdığını çünkü tasarım kavramının en temel insan aktivitesini anlattığını ifade ederken bu alanın tarihsel ve toplumsal sınırsızlığını da belirlemiş oluyor. Fotoğraf makinesini kullanan birinin çektiği hiçbir topluluk fotoğrafında bulunamaması gibi varlığı bilinen ancak görülemeyen, ${ }^{45}$ tüm evrelerinde yer alan ve aynı anda hem yaratanı hem de tüketeni olabilen insanın açığa çıkması engellenemeyen güçlü bir özelliği olarak somutlanan tasarım kavramı, kendi bütünselliğinden aldığı güçle bir başkaldırıyı da içinde barındırmaktadır. Bir insanın yaşam alanını düzenlemesi, giysilerini seçmesi, doğa ile mücadelesi, düşünsel çıkarımları, yaratıcılığı ve değerlendirme/yorumlama gücü, buluşları ve bunları çevresiyle paylaşması gibi sıradan yaşamlara günlük katkı sağlayarak anlam kazandıran tasarım kavramının özünde bulunan itaatsizlik ${ }^{46}$ aynı zamanda toplumsal ilerlemenin de yapı taşıdır. "Tarih okumuş herkes bilir ki, itaatsizlik insanın asıl erdemidir. Ilerleme itaatsizlik yoluyla kaydedilir, itaatsizlik ve başkaldırı yoluyla."47 Tasarımın "engellenemeyen bir özellik" olarak birey üzerinden toplumsal yapıya taşındığı, nicel değişikliklerin güçlü nitel dönüşümlere yol açtı̆̆ı, ilkel komünal toplumla başlayıp günümüzü içine alan bu geniş kapsamını; Stalin' in toplumların nitel (devrim) dönüşümlerinin çok daha ağır ilerleyen

44 Victor Papanek, Design for the Real Word, (Academy Chicago Publishers 1985), isimli kitabında şu ifadeyi kullanmıştır: "Everyone is a designer because design is a basic human activity".

45 Gündelik basit hayatlarda dahi yaşam alanlarını çevreleyen, insanların hayatlarını kolaylaştıran ancak tasarımcısının kim olduğu bilinmeyen, (ticari ya da değil) kültürel dokunun parçası olmuş tasarım ürünleri vardır. Bunların çoğu siz doğmadan çok önce de kullanıldığı için yaşamın doğal bir parçası, sanki doğada kendiliğinden bulunan bir nesneymiş gibi algılanır ve tüketilir. Aynı durum belirli uzmanlık alanı olarak kurgulanan tasarım soyutlaması için de geçerlidir; kullandığınız kalem ya da buzdolabının tasarımcısını değil yalnızca markasının bildiğini hatırlayınız.

46 Burada alışkanlıkları değiştirerek, dogmaları yıkarak ve daha iyisini arayarak kendiliğinden gelişen bir itaatsizlik ve başkaldırıdan söz edilmektedir.

47 Oscar Wilde, Sosyalizm ve İnsan Ruhu, (İstanbul: Re Yayınları 2006), s.23. 


\section{Devrim BARAN}

nicel (evrim) süreçlerle hazırlandığını dile getirdiği açıklamasıyla anlatmak iyi bir seçim olacaktır: "Evrim devrimi hazırlar ve onun zeminini yaratırken, devrim de evrimi tamamlar ve onun etkinliğini daha ileri götürür". ${ }^{48}$ Doğaya ya da insana başkaldırı olarak gelişen, şekillenen ve sahiplik ilişkilerini görünür kılan tasarım ürünlerinin yavaş ilerleyen evrimsel (nicel) süreçleri, sonunda toplumsal dönüşümlerin ve devrim özelliğindeki (nitel) gelişmelerin tanıklığını üstlenmiştir.

Tasarım kavramı, farklı uzmanlık alanlarıyla yaratılan köşeli parantezlerin içine alındığında ise nitel dönüşümlerin yaşandığı endüstri, şehir, mimari, çevre, iletişim, grafik ya da ekran tasarımı gibi uygulamalı alan/disiplinlerle karşılaşılır. Birçoğu Endüstri Devrimi'nden sonra uzmanlık alanına dönüşmüş bu disiplinler, tasarım kavramını zaman içinde planlanmış çıkarların kesiştiği sömürü zeminine taşıyarak

Üsküdar University Journal of Social Sciences Year:2 Issue:3 kapitalizmin ve dolayısıyla tüketimin hegemonik/ideolojik arac1 düzeyine indirgemişlerdir. Gördügümüz, algıladığımız, anlamlandırmaya çalıştığımız şu dünyada tahakkümün üzerini örterek "sınırsız ilerleme ve herkes için mutluluk" vaatlerini görünür kılan tasarım kavramının (ek olarak mesleki uygulamalarının nesnel şartlarıyla bu uygulamalardan nasıl yararlanıldığının çoğunluğu tarafından düşünülmeyen tasarım profesyonelleri) kapitalizmin kanatları altında şekillenen sanal dokusuyla her coğrafyada karşılaşılmaktadır. Irkçı, muhafazakâr, fanatik, emperyalist, bağımlı, hedonist, ${ }^{49}$ iletişimsel vb. kimliklere bürünen bu karşılaşmaların oluşturduğu yıkım/dönüşüm, pozitivizmin görmediği tasarımın karanlık yüzüdür. "Güçsüz olanın, iktidarın huzurunda bir maskenin arkasına gizlenmek için açık ve zorlayıcı nedenleri varsa, güçlülerin de kendilerine tâbi olanlar karşısında bir maske takmak için zorlayıcı nedenleri" ${ }^{50}$ olduğu ve tasarımın karanlık yüzünün bu amaçla çok iyi kullanıldığı söylenebilir.

48 J.V. Stalin, Anarşizm mi Sosyalizm mi? çev. İsmail Yarkın, (İstanbul: İnter Yayınları 1997), s.16. 49 Hedonizm (Hazcılık): Haz veren ya da acıdan kurtaran şeyi "iyi”; acıya sebep olan şeyi de "kötü" olarak tanımlayan etik teorisi. "Hazzın en yüce iyi" demek olduğu fikri, ahlak problemlerine katkı ve kaba bir yaklaşma tarzından başka bir şey ifade etmez. M. Rosenthal, P. Yudin, Materyalist Felsefe Sözlüğü, (İstanbul: Sosyal Yayınları 1977), s. 199.

50 J.C. Scott, Tahakküm ve Direniş Sanatları, çev. Alev Türker, (İstanbul: Ayrıntı Yayınları 1995), s.34. 
Bu dönemde, üzeri örtülen kişisel ve toplumsal tüm patolojilerin, "yakışık alır olan" her şey ve her durumun "sınırlarını zorlama" denemesi olarak karşımıza çıkan tasarım varlığı da, durmaksızın üretilen siyasi, ahlaki, ticari, akademik dilin gerçek yüzünü saklayan bir maske niteliğine dönüşmüştür.

Maskelenerek dikte edilen kavramları genellikle slogan düzeyinde özümseyebilen "toplum”, düşünüldüğünde dokunulamayan bir şey olmasına karşın tasarımın köşeli parantezleri dolayımıyla farklı formlarda görünür k1lınabilir; sanayi toplumu, burjuva toplumu, gösteri toplumu, tüketim toplumu ya da bilgi toplumu gibi. Örneğin enformasyon teknolojileri ve iletişim araçlarının şekillendirdiği son dönemlerin çok sık kullanılan "bilgi toplumu" ${ }^{1} 1$ kavram1, tasarlanan bilginin yine tasarlanarak oluşturulan mecralarda ve tasarlanmış zaman dilimlerinde tüketilmesine izin verilen yeni bir toplumsal yapıyı anlatmaktadır. Arzu nesnesine ${ }^{52}$ dönüşmüş çıktıların/tasarım varlıklarının yoksunluğunu duyumsayan toplumun gerçek ve bilinç arasında yaşadığı gelgitleri «modern insan sıkıntısına» indirgeyebilen tasarım kavramının, kabul edilmesi gereken doğru, tüketilmesi gereken nesne, sahip olunması gereken yaşam alanları ya da kazanılması gereken eğitim, yetenek, para gibi dogmaları, içinde bulunduğu döneme uygun formlarda tekrar ve tekrar üretebilen, toplumsal kabullerini mümkün kılan bir etkinlik alanına sahip olduğu ortadadır.

51 "Bilgi Toplumu" kavramının temelleri 20. yüzyılın başlarında atılmış olsa da Marshall Mc Luchan'ın 1962 'de ilk kez "iletişim çă̆ı" kavramını, hemen ardından Fritz Machlup'un da "bilgi toplumu" kavramını kullandığı bilinmektedir. Teknoloji vurgusu öncelenerek açıklanan kavram, kanalların çeşitlenmesi ve bilginin metalaşması üzerinden oluşturulan yeni bir toplum yapısını anlatır.

Haluk Geray, "İletişim, Bilgi Toplumu ve Küreselleşme", Emperyalizmin Yeni Masall: Küreselleşme içinde, der. Işık Kansu, (Ankara: İmge Yayınları 1997), ss. 34-45.

Bülent Yılmaz, Bilgi Toplumu: Eleştirel Bir Yaklaşım, (Ankara: Hacettepe Üniversitesi Edebiyat Fakültesi Dergisi), cilt 15, sayı 1, ss. 147-149.

Mehtap Yeşilorman, Firdevs Koç, Bilgi Toplumunun Teknolojik Temelleri Üzerine Eleştirel Bir Bakış, (Elazığ: Frrat Üniversitesi Sosyal Bilimler Dergisi 2014), cilt 24, say1 1, ss. 117-119.

52 Arzu yok edilemez ama arzu nesnesi yok edilebilir ya da dönüştürülebilir. Eğer arzu açlıksa, herhangi bir yemek arzu nesnesi konumuna gelir. Açlık temel bir arzu olduğu için daima tekrarlayacak, doyurulacak ve başa dönerek yeniden başlayacaktır. Ancak yemek bir arzu nesnesi olarak çeşitli biçimlere, bir başka yemeğe dönüştürülebilir ya da tüketilerek (yok edilerek) ortadan kaldırılabilir. Madan Sarup, Post-Yapısalcllık ve Postmodernizim, çev. Abdülbaki Güçlü, (İstanbul: Bilim ve Sanat Yayınları 2004), s. 33. 


\section{Devrim BARAN}

Aslında uzun zamandır gözümüzün önünde ve tam orta yerde, her ayrıntıda bir tasarım zehirlenmesi yaşandığının artık söylenmesi gerekiyor; çünkü kulağa çok bilindik gelen bu kavram dolayımıyla gelişen/oluşan dünya algısı, toplumsal bilinç yitimine neden olmaktadır. Buraya kadar yapılan saptamalar, tasarım kavramının estetize ederek dönüştürdüğü nesnel ve düşünsel spektrumun genişliği konusunda sanırım bir fikir vermektedir.

Farklı uzmanlık alanlarının farklı mecralarda ve farklı iletişim özelliğiyle şekillenen çıktılarının (tasarım ürünleri), hep yapıldı̆̆ 1 üzere üretim aşaması ve teknik yeterlilikler, yaratıcı süreçler ya da tüketim aşamaları gibi başlıklara ayrılarak (soyut parçaları bütünden kopartarak) ele alınmasının, akademik anlamda sınırlı bir tasarım algısına neden olduğu ortadadır. Soyut parçalar altında yapılan tasarım incelemelerini, gerçekte her şeyin şu ya da bu şekilde birbirine bağlı (ayrılamaz) ve karşılıklı hareket

Üsküdar University Journal of Social Sciences Year:2 Issue:3 içinde olduğu bilgisinden yola çıkarak, örneğin masa olarak kullanılan bir nesnenin göründüğü gibi olması (diğer masalardan farklı olmasının), bu yöndeki seçimler ve nedenleri, yüklenen işlevler vb. olgu, olay ve süreçlerin farklı düzlemlerde yer alan bağıntılar içinde değerlendirilmesi yaşamlarımızı dolduran ve bir hayalet gibi varlığını sürdüren tasarım kavramını daha anlaşı1ır kılacaktır. Dolayısıyla tasarım kavramını anlama pratiğinin çıkış noktası olarak, tasarım kavramının merkeze alındığı bir yöntemin işe yaramayacağ 1 da gayet açıktır; çünkü ulaşılacak nokta yine o anda göründüğü gibi algılanan masanın (sınıflandırılan nesnenin) kendisi olacaktır. Doğru yöntem, diyalektik kavrayışla herhangi bir tasarım nesnesini (kavramı değil) merkeze koyarak, bu nesnenin varlık sebebi ve görünüşü, üretim ve tüketim süreçleri ile bunların hepsini etkileyen insan faktörü gibi soyut parçaların, karşıtların mücadelesi ${ }^{53}$ üzerinden oluşturulan düşünce düzlemine çekilerek tartışıldığı bir tasarım kavrayışına ulaşmaktır. Karşıtların birbirinden soyutlandığı ve birbirinden kopuk ayrı başlıklardan oluşan bir sistematikle ele alınan (egemen akademik söylem) çalışmalar,

53 Diyalektiğin en önemli unsuru olarak kabul edilen karşıtların mücadelesine ilerleyen sayfalarda daha geniş biçimde yer verilmiştir. 
Tasarımın Diyalektiği: Diyalektik Kavrayıșla Tasarım Kavramına Dokunma Denemesi

karşıtlardan birinin var olmadığı durumda diğerinin de var olamayacağını, tüm hareket, değişim ve dönüşümlerin ancak karşıtların mücadelesi ile açıklanabileceğini reddetme cesaretliliğini gösteremese de, hep olduğu gibi görmezden gelmeyi denemektedir.

\section{Tasarım Kavramına Giden Diyalektik Yol}

Gerçek, olup biten olaylar bütünü değildir, tarihsel bir süreçtir ve bilginin en alt düzeyinden üst düzeylere geçiştir; gerçeğin yani bilimin hareketi, karşıtların çatışmasıdır şeklinde formülasyonla diyalektik yöntemi düşün dünyasına ilk kazandıran Hegel'in yaklaşımının, Marx tarafından idealist kabuğundan arındırılarak tam tersine çevrildiğini Engels şöyle dile getirmektedir: “...beynimizin düşüncelerini objelerin yansıları gibi değerlendirerek diyalektik, hem dış dünyanın hem de insan düşüncesinin genel hareket yasalarının bilimi durumuna getirilmiş oldu. Ne var ki, bununla, bizzat düşüncenin diyalektiği, gerçek dünyanın diyalektik hareketinin bilinçli bir yansisı durumuna geldi ve böylece Hegel'in diyalektiği başyukarl çevrildi, ya da daha doğrusu üzerinde durduğu kafasından alınarak yeniden ayakları üzerine oturtuldu". ${ }^{54}$ Hegel için diyalektik, dünyanın kendi hareketi ve hakiki bilgi yönetimidir; aynı zamanda “(...) aklın diyalektik gelişimi, nesnel olan kavramın birbirini izleyen gelişimi biçiminde gerçekleştiği ve kavramın her gelişim basamağl, varlık ile düşünce arasında var olduğu kabul edilen bir birlikten dolayl, aynı zamanda öğrenmenin de bir basama $\breve{g}_{l}{ }^{, 55}$ olarak kabul edilmesiyle büründügü idealist kabuğundan arındırıldığında, felsefede, hareket ve gelişimi doğanın ve toplumun maddi sınırları içinde, bunların yansımasını da öğrenme sürecinde ortaya koyan bir devrim niteliğine ulaşır. Bilimsel bilginin tarihsel süreçte saptadığı olgulardan yola çıkarak maddenin ve fenomenin karşılıklı ilişki içinde bulundukları ve koşullandıkları, yaşadığımız dünyanın düşüncede oluşan yansılarının da sonsuz bir hareket

54 Marx ve Engels, Felsefe Incelemeleri, çev. Cem Eroğlu, (Ankara: Sol Yayınları 1968), s. 46. 55 Manfred Buhr, Alfred Kosing, Bilimsel Felsefe Sözlüğ̈̈, çev. Veysi Bildik, (İstanbul: Konuk Yayınları 1999), s. 111. 


\section{Devrim BARAN}

ve gelişim içinde bulunduğu gerçeğine dayanan diyalektiğin özünü Lenin'in dile getirişiyle "en derine uzanan ve tek yanlılıktan en uzak öğreti biçimi" oluşturmaktadır.

Çalışmanın bu kısmında, Marx ve Engels, ${ }^{56}$ Stalin,,${ }^{57}$ Troçki,,${ }^{58}$ Politzer,,${ }^{59}$ Williams, ${ }^{60}$ Çubukçu, ${ }^{61}$ Tunal1, ${ }^{62}$ Boguslavsky/Karpuşin/Ratikov/Çertikin/ Ezrin, ${ }^{63}$ Buhr ve Kosing, ${ }^{64}$ Aktolga, ${ }^{65}$ Öner ${ }^{66}$ ve Turan' dan ${ }^{67}$ yararlanılarak bir diyalektik anlatım oluşturup bu kavrayışla, tasarım kavramının somut yapısı detaylandırılmaya çalışılacaktır. Böylelikle, önceki bölümlerde tasarımın kavram olarak soyut-somut çözümlemesi sonucu ulaşılan somut bütünün, tasarım özelinde daha anlaşılabilir hale getirilmesi hedeflenmektedir.

Diyalektiğin ilk özelliğinde, bütün şeyler birbirine bağlıdır ilkesiyle tam ve bağımlı bir bütüne işaret edilmektedir. Madde ve olaylar birbiriyle

Üsküdar University Journal of Social Sciences

Year:2

Issue:3
56 Karl Marx, Friedrich Engels, Komünist Manifesto, çev. Etem Levent Bakaç, (İstanbul: Zeplin 2015), ss. 9, 35-52.

Marx ve Engels, Felsefe Incelemeleri, çev. Cem Eroğlu, (Ankara: Sol Yayınları 1968), ss. 43-65.

Engels, Tarihsel Materyalizm Üzerine Mektuplar 1890-94, çev. Öner Ünalan, (Ankara: Bilim ve Sosyalizm Yayınlar1 2000), ss. 28-39.

Friedrich Engels, Doğanın Diyalektiği, çev. Arif Gelen, (Ankara: Sol Yayınları 1977), ss. 85-114.

57 Stalin, Diyalektik Materyalizm ve Tarihsel Materyalizm, çev. Zeynep Seyhan, (İstanbul: Bilim ve Sosyalizm Yayınları 1989), ss. 12-20.

Stalin, Anarşizm mi Sosyalizm mi?, çev. İsmail Yarkın, (İstanbul: İnter Yayınları 1997), ss. 13-26.

58 Lev Troçki, Gündelik Hayatın Sorunları, çev. Yılmaz Öner, (İstanbul, Yazın Yayıncılık 2000), ss. $363-373$.

59 Georges Politzer, Felsefenin Temel İlkeleri, çev. F. Karagözlü, (İstanbul: Sosyal Yayınları 1977), ss. 25-113.

60 Raymond Williams, Anahtar Sözcükler, çev. Savaş Kılıç, (İstanbul: İletişim Yayınları 2007), ss. 128-130.

61 Aydın Çubukçu, Teoride ve Eylemde Diyalektik Materyalizm, (İstanbul: Evrensel Yayın 2008), ss. 43-82.

62 İsmail Tunal, Tasarım Felsefesine Giriş, (İstanbul: Yapı-Endüstri Merkezi Yayınları 2002), ss. 18-21. 63 Boguslavsky/Karpuşin/Ratikov/Çertikin/Ezrin, Diyalektik ve Tarihsel Materyalizmin Alfabesi, çev. Şiar Yalçın, (Ankara: Bilim ve Sosyalizm Yayınları 1990), ss. 61-111.

64 Manfred Buhr, Alfred Kosing, Bilimsel Felsefe Sözlüğ̈̈, çev. Veysi Bildik, (İstanbul: Konuk Yayınları 1999), ss. 109-114.

65 Münir Ramazan Aktolga, Bilimsel Teknolojik Devrim ve Diyalektik, (İstanbul: Ulusal Kültür 1991), ss. $25-47$.

66 Yılmaz Öner, Bilimlerde ve Sanatta Diyalektik, (İstanbul: belge Yayınları 1990), ss. 19-26, 96-99, 165. 67 Mehmet İnanç Turan, Marx’ın Grundrisse si, Ankara: Ütopya Yayınevi 2015), ss. 17-29. 
Tasarımın Diyalektiği: Diyalektik Kavrayıșla Tasarım Kavramına Dokunma Denemesi

ilişki içindedir, her şey kendini kuşatan öbür şeyler tarafından (bir bütünün parçası olarak kapsandığı için) koşullandırılır. Herhangi bir fenomenin onu çevreleyen koşullardan koparılması anlam yitimine sebep olur (bireyin bilinci toplumun dışında anlaşılamaz), çünkü hep dile getirildiği gibi gerçek bir bütündür. Dolayısıyla çevresindeki olayların koşullandırdığı ve bütünle ayrılmaz bağlar içinde olan her olayı diyalektikle açıklamak olanaklıdır. Her şey zaman ve mekân şartları içinde gelişir; çünkü diyalektik sosyal fenomenleri, tarihsel süreçlerde bağlı oldukları karşılıklı hareket içinde değerlendirerek açıklayabilir. Sonuç olarak bir durum, olay ya da çaba, onu oluşturan ve açıklayan şartlar açısından değerlendirilmelidir.

Diyalektiğin ikinci özelliği olan her şey dönüşür ilkesi, bir şeylerin sürekli doğduğu, geliştiği, parçalanıp öldüğü, bir hareket ve değişim, yenilenme ve gelişim halinde olduğunu açıklamaktadır: Değişim evrensel, gelişim aralıksız ve süreklidir. Hareket ${ }^{68}$ gerçeğin ikincil yanı değildir, "toplum artı hareket" ya da "bilinç artı hareket" diye bir şey olamaz; doğada da tolumda da gerçek harekettir, süreçtir. Olaylar, yalnızca karşılıklı bağıntıları ve dayanışmaları açısından değil, ayrıca bu olayların hareketleri, değişmeleri, gelişmeleri, varoluşları ve var oluştan yok oluşa geçişleri açısından da düşünülmelidir. Engels'in söylediği gibi diyalektik "ş̧eyleri ve onların zihindeki yansımalarını, temel olarak karşılıklı ilişkileri, birbiriyle bağıntıları, hareketleri, doğuş ve yokoluş koşulları içinde ele alınır" ${ }^{69}$

Diyalektiği açıklayan üçüncü ilke nitel değişimdir. Diyalektik, önemsiz ve belirsiz nicel değişimlerin (açık) temel nitel değişimlere yol açtı̆̆ını ve bir durumdan ötekine kesin ve hızlı geçişleri doğanın ve toplumun evrensel bir yasası olarak görür; bu dönüşümler küçük nicel değişimlerin zorunlu bir sonucudur, madde kendi öz haliyle yeniyi yaratır. Dolayısıyla nicel değişim ile nitel değişim arasındaki zorunlu bağıntı evrensel bir gerçektir. Keza

68 Engels hareketi şöyle açıklamaktadır: "Maddenin varoluş tarzı olarak, maddede yer alan ve onun ayrllmaz özelliği olarak en geniş anlamda hareket, basit yer değiştirmeden düşünceye kadar, evrende meydana gelen bütün değişimleri, bütün süreçleri kucaklar". Friedrich Engels, Doğanın Diyalektiği, çev. Arif Gelen, (Ankara: Sol Yayınları 1977), s. 94.

69 Friedrich Engels, Doğanın Diyalektiği, çev. Arif Gelen, (Ankara: Sol Yayınları 1977), s. 89. 


\section{Devrim BARAN}

kavramlar da (nitel özellik), duyumlardan başlayarak pratiğin tekrarıyla (nicel özellik) oluşurlar. Duyum kendi başına gerçeğin belirli bir yansısıdır ve diş görünüm bilgisini verir. Ancak sosyal yaşamda sürekli tekrarlanan pratikler gerçeği derinleştirerek diş görünüşün ötesindeki iç süreçlerin de kavranmasını sağlar; kavramlar böylelikle oluşur. Gerçeğin zihindeki yansısıyla belirginleşen nicelik-nitelik süreçleri duyumdan (bilginin alt biçiminden) kavrama (bilginin üst biçimi) geçiş, ilerleyen sürekli bir harekettir. $\mathrm{Bu}$ nedenle diyalektiğe göre gelişme, dairesel bir hareketlilik ya da önceki tecrübelerin tekrarı olarak düşünülmemelidir; eski bir nitel durumdan yeni bir nitel duruma geçen, basitten karmaşığa, alçaktan yükseğe doğru bir gelişme olarak bilinmelidir. Bu açıklamalar 1şı̆̆ında diyalektik üçüncü özelliğiyle, pratiğin önemine ve işlerliğine dikkat çekmektedir.

Üsküdar University Journal of Social Sciences Year:2 Issue:3

Diyalektiğin dördüncü temeli, doğadaki nesnelerin ve fenomenlerin ve de her olayın yapısındaki iç çelişkilerin varlığıdır. Bu görüşten hareketle her şeyin olumlu ve olumsuz, ölen ve gelişen yanları, geçmişi ve geleceği vardır. Gelişmenin ilkesi olarak çelişkinin incelenmesi, çelişkinin temel karakterlerini oluşturur: Çelişki içtedir ve yenileştiricidir (karşıtların birliği). İşte bu karşıtlar arasındaki savaşım yani nicel değişimlerin nitel değişmelere dönüşmesi biçiminde beliren iç kapsamı Lenin, şeylerin asıl özündeki çelişmenin incelenmesi olarak kavramsallaştırır. Sosyal gerçeği oluşturan tüm süreçler de çelişkiyle açıklanır; çelişki öncelikle toplumun meydana gelişini açıklar. İlkel komünden başlayarak günümüz toplumsal sınıflarına kadar çelişki tarihin itici gücü olmuştur. Üretim araçlarına sahip olan kapitalist burjuvazi ile proletarya arasındaki çelişki olmazsa kapitalizm de olmaz, çünkü rekabet kendi karşıtı haline gelmiştir. Diyalektiğin hem yöntemsel ilkelerinin uygulanması hem de bir mantık sistemi ve bilgi teorisi olarak iş görmesinin, toplum yaşamının ve toplum tarihinin incelenmesi adına ne kadar gerekli olduğu anlaşılmaktadır. Dünyada olaylar her şeyden ayrı ve tek başlarına değilse, bütün olaylar birbirlerine bağlı ve birbirlerini karşı1ıklı olarak koşullandırıyorsa, açıkça görülür ki, tarihteki bütün sosyal 
Tasarımın Diyalektiği: Diyalektik Kavrayıșla Tasarım Kavramına Dokunma Denemesi

sistemler ve sosyal hareketler de o sistemi ya da sosyal hareketi doğuran ve o sisteme ilişkin koşullar açısından değerlendirilebilirler. Her şey koşullara, zamana ve yere bağlıdır.

Yukarıda isimleri verilen yazarlardan yararlanılarak oluşturulan bu diyalektik kavrayış özetinin kılavuzluğunda, tasarımın bir form, anlam ve işlevsellik kazandırarak çoğunlukla endüstriyel üretim teknikleriyle nesneye dönüşen (tasarım varlığ $1,{ }^{70}$ tasarım ürünü) ve metalaşan (aslında meta fetişizmi ${ }^{7 l}$ ) sürecin tüketim aşamasıyla birlikte bir bütün/sonuç olduğu rahatlıkla görülebilmektedir. Bütünü oluşturan ve çevresel olan her şey, birbirine koşut zaman ve mekân şartları dolayımıyla farklılaşabilir. Biraz daha açmak gerekirse, merkeze konulacak bir tasarım ürününün sahip olduğu form, anlam ve işlevsellikle doğrudan bağıntılıdır; bağıntı ise tüketim alışkanlıkları ve karlılık üzerinden belirlenmektedir. Bu söylem tersten okunduğunda, renk ve form tercihleri (eğilimleri) gibi soyut parçaların az çok tahmin edilebildiği bir coğrafyada tasarım kavramı bu belirleyicilerin (soyut parçaların) öncelendiği seçimlerle şekillenmeye başlarken bütünü düşüncede somutlaştıran aidiyet, statü, kullanım değeri ve tatmin düzeyi gibi giydirilmiş anlam yapıları da varlık göstermeye başlar. Form, anlam ve işlevsellik üçlüsünün birbirini bütünleyen ve etkileyen iş akışıyla görünür olmaya başlayan tasarıma dokunabilmek için (raflarda yerini alabilmesi için) üretim ve tüketim basamaklarının da sürece katılması gerekmektedir.

70 “Tasarım varlığı”, Prof. Dr. İsmail Tunalı’nın Tasarım Felsefesine Giriş adlı kitabında sıklıkla değindiği şekliyle kullanılmıştır. Örneğin: “ (...) Bir tasarım varlığı olma bakımından teknik ürünlerle sanat yapitları arasında bir ortaklı vardır. Örneğin, elimde tuttuğum ekmek bıçă̆ bir tasarım varlığl olduğu gibi, duvarda asılı duran resim de tasarım varlı̆̆ldır." İsmail Tunalı, Tasarım Felsefesine Giriş, (İstanbul: Yapı Endüstrisi Merkezi Yayınları 2002), s. 21.

71 Meta Fetişizmi: "Bir sosyal iliş̧kinin şeyler arası bir iliş̧ki haline bürünmesi. Meta üretimi tarzında, üretim ilişskileri doğrudan doğruya gözle görülür, elle tutulur olarak ortaya çıkmazlar. Bu ilişskiler, meta üretimi tarzında, üstü örtülü, maskelenmiş bir durumdadır ve insan gözüne metalarda maddeleşmiş olarak, fantastik bir form içinde görünürler. (...) Fetişizm, en yüksek derecesine kapitalizmde ulaşır, çünkü her sosyal fenomenin meta biçimine bürünme eğilimi bu üretim tarzında gerçekleşir. Meta ne derece birikirse, insanlar, yani üreticiler de o derece egemenlik altında, köleleşmiş, tutsaklaşmış görünürler". Maurice Bouvier-Ajam, Jean Ibarrola, Nicolas Pasquarelli, Marksist Ekonomi Sözlügüu, çev. B. Aren, İ. Yaşar, (İstanbul: Sosyal Yayınları 1977), s. 362. 


\section{Devrim BARAN}

Üretim eyleminin son bulması ve tüketim sürecinin başlamasından hemen önce unutulmaması gereken bir diğer halka da pazarlama faaliyetleridir. Tasarımın bambaşka bir koluyla sürdürülen pazarlama, o tasarım ürününe duyulacak aidiyet ve sahiplenme güdülerini tetikleyen bir mekanizma olarak sürecin en başlarında gözlemlediğimiz seçimleri doğrudan etkileyen ve şekillendiren önemli bir halkadır.

"Bütün şeyler birbirine bağlıdır" ve "gerçek bütünün kendisidir". Her sezon farklılaşan moda ürünler üzerinden, çağdaş ya da modern, hızlı ya da klasik, çekici ya da sıradan vb. sanal seçeneklerin bağımlılı̆̆ıyla şekillenen toplumların arasında bir hayalet gibi dolanan tasarım kavramını bilimsel düzeyde açıklamanın, işe, artık hatırlanmayan en özdeki örtünme ihtiyacından başlayan diyalektik kavrayış haricinde bir başka yolunun olmadığı açıktır. Örneğin politik, sosyal/kültürel ve gündelik olayları

Üsküdar University Journal of Social Sciences Year:2 Issue:3 topluma aktaran gazeteler öncelikle bir tasarım ürünü olarak tüketilen haber mecralarıdır. Ancak gazetenin sayfalarını çeviren hiç kimse ilk olarak bir tasarım ürünü satın aldığını düşünmez. Başka bir deyişle tasarım kavramı (somut bütün) bir gazete üzerinden (tasarım ürünü) kendi varlığını öncelikli olarak hissettirmez. Bu gazete sayfalarının bir tasarımcı eliyle düzenlenmeden yalnızca düz metinler olarak sunulduğu düşünüldüğünde, şu ana kadar oluşan gazete algısının/gerçeğinin (nesnesinin) tasarım eylemi üzerinden nasıl yok olduğu ve gazete nesnesinin geçireceği bu dönüşümün (zaman içinde insan düşüncesinde oluşan gazete algısının) bu şekilde anlatımının, maddeyi (gazete) insan düşüncesi üzerinden (idealist felsefe) yeniden tanımlamakla sınırlı olduğu ortadadır. Tasarım kavramı, bir tasarım nesnesi olan gazete üzerinden diyalektik bakış açısıyla ele alındığında ise, sayfalarda yer alan haber metinleri ve görsellerinin göründüğü şekliyle düzenlenmelerinin rastlantısal (ya da salt estetik kaygılarla oluşturulmuş) bir durum olmadığı, hangi haber metninin hangi fotoğraf ya da görsel (nicel-soyut parça) ile kullanılacağı ve bu nicel/soyut unsurların sayfanın neresinde yer alacağı (iç çelişki), diğer nicel unsurlarla yan yana geldiklerinde oluşturdukları bütün (nitel, sayfanın geneli; gerçek bütün; somut gerçeklik), bu bütünün aracılığıyla taşınan ideolojik anlam/düşünce 
Tasarımın Diyalektiği: Diyalektik Kavrayıșla Tasarım Kavramına Dokunma Denemesi

yapıları, bu anlamın nicel unsurların sıralamalarındaki her değişimle (her şey birbirine bağlıdır, her şey dönüşür) nasıl farklılaştı̆ğ rahatlıkla konuşulabilecektir. Hatta bunlar konuşulmadan önce, haber kavramı ve sunumu, toplum ve haber bağıntısı, haberin gazete formu ve tasarımı, gazete ve sahiplik ilişkileri, gazete ve siyasi erk, gazete ve ihale/reklam veren ilişkileri vb. karşıtlıklar/soyut parçalar, merkeze konan tasarım ürünü yani gazete nesnesinin parçalanan anlam yapıları olarak düşüncede tekrar oluşturulup gazete üzerinden tasarım kavramı daha geniş kapsamlı olarak var edilebilir. Bu var ediş sonunda o gazetenin niçin öyle göründüğü (tasarlandığı) anlaşıldığında (görünüşten öze), tasarım artık dokunulabilen ve düşüncede somut bir kavram halini alabilecektir.

\section{Sonuç}

Her bir tasarım ürününün nicel hareketlilik olarak ele alındığ 1 ve bu nicel birikimin keskin toplumsal dönüşümlere/farklılaşmalara yani nitel sonuçlara yol açtığı bilgisini aktaran diyalektik kavrayış, tasarım kavramını özel bir çıkar gözetmeksizin (ya da insanlığın genel çıkarları için) insan yaşamın kolaylaştıran sonuçların her birine ya da insanlığı koşulsuz kullanım ve doyumsuz tüketim arzusuyla doldurulan belirlenmiş kuralların tam içine taşıyacak ayrışmayı sağlayabilecek yegâne yöntemdir. Ölümcül silahları ya da insanları köleleştiren iletişim kanallarının görünür olmasını kapsayan tasarım kavramının günümüz koşullarında bir bütün olarak incelenmesi, yalnızca kapitalist insan doyumsuzluğunu ve sınıfsal ayrımları gösteriyor. Bu durum Engels'in, Komünist Manifesto'nun 1883 Tarihli Üçüncü Almanca Baskı İçin Önsöz'ünde yalnızca ve tümüyle Marks'a ait olduğunu dile getirdiği temel düşüncede açık bir şekilde ifade edilmiştir: "Ekonomik üretim ve her tarihsel çağın bundan zorunluluk olarak doğan toplumsal yapısı, o çağın siyasal ve entelektüel tarihinin temelini oluşturur. Bunu takiben (ilk çağ ortak toprak mülkiyetinin ortadan kalkmasindan buyana) tüm tarih, sinıf mücadelelerinin yani sömürülen ile sömürenlerin, toplumsal gelişmenin farklı basamaklarında var olan ezilen ile ezen sınıflar 


\section{Devrim BARAN}

arasındaki mücadelelerin bir tarihidir..."72 Tasarım kavramı da Marx'1n bahsettiği bu tarihin en yakın ve en sadık takipçisidir.

"Guy Besse ve Maurice Caveing"ᄁ3 insan pratiğinin, insanı oluşturan ve onun bilim, teknik, sanat gibi ayırt edici eylemlerinin tümünün ve de var olduğu zamandan itibaren biriktirdiği tecrübelerinin toplamı olduğundan bahsederler. İnsan pratiğinin tarihsel, kültürel, ekonomik ve toplumsal göstergelerinin özünde/temelinde bulunan izlerini takip ederek üzerinden önemli okumaların yapılabildiği tasarım kavramı, kendi başına sömürü ve aç gözlülüğün pratik uygulamalar alanı/yığını olmadığı gibi, elindeki reçelli ekmeğiyle evinin bahçesinden dişarı çıkması yasaklanan yaramaz bir çocuk da değildir. İnsanlığa kötülük eden, sömürüyü artıran, düşmanlığ1 ve ayrışmayı, lüksü ve aç gözlülüğü yücelttiğini önceleyen eleştirel düşüncenin saptadığı tüm olumsuz etkilerinin yanı sıra insanı baştan aşağ 1

Üsküdar University Journal of Social Sciences Year:2 Issue:3 donatan, yükselten, bilgi ve düşünce gücü kazandıran, heyecanlandıran ve harekete sevk eden amaçların, anlamların ya da öğretilerin görünür halidir ayn zamanda.

Albert Bayet "bilim ahlaka aykırı değildir ancak ahlak dışıdır, çünkü bilimin gerçeği aramaktan başka kaygısı yoktur, iyi ve kötü ile ilgilenmez, bir ideal aramak için bilime başvurmak da ahmaklıktır" der. Benzer bir akıl yürütme ile tasarım kavramının kendisinin iyi ve kötü ile ilgilenmediğini, üzerine giydirildiği nesnel görünümlerin (soyut parçaların) insan eliyle yaratılan sonuçlar (somut bütün) olduğunu söylemek gayet mümkündür. Gerçeğin yok sayıldığı ya da salt görünüş üzerinden bilinçli sınırlılığın kısırlığında yapılan tanımlama ya da kavramsallaştırmaların ise planlanmış çıkarların kesiştiği akademik sömürüden başka bir şey olamayacağı açıktır. Çünkü tasarım kavramının emir komuta zincirinde var edilemeyen ele avuca gelmez zekâsı, ne "topluma rağmen"(nicel) olabilir, ne de "toplum diş1/üstü” (devrim).

72 Karl Marx, Friedrich Engels, Komünist Manifesto, çev. Etem Levent Bakaç, (İstanbul: Zeplin Kitap 2015), s. 14.

73 Guy Besse, Maurrice Caveing, "Önsöz», Felsefenin Temel İlkeleri içinde, Georges Politzer, çev. F. Karagözlü, (İstanbul: Sosyal Yayınları, 1977), s.7.

74 Albert Bayet, Bilim Ahlakı, çev. Vedat Günyol, (İstanbul: Çan Yayınları 1963), s. 23. 
Tasarımın Diyalektiği: Diyalektik Kavrayıșla Tasarım Kavramına Dokunma Denemesi

Maddesel/nesnel bir organ olan beyin ile düşünce kavramı arasındaki ilişsinin tasarım varlığ 1 ve tasarım kavramı arasında da kurulabileceği, ister "engellenemeyen insan özelliği” düzleminde istenirse de "uzmanlık alanı olan bir disiplin" düzleminde sürdürülsün, bu kavramın, alternatiflerin araştırıldığ1 düşünsel/zihinsel bir arayış/kavrayış süreci olarak kabul edilmesi "tasarımın bir anlam yaratma, üretme çabası/etkinliği" olduğunun da kabulünü zorunlu kılmaktadır. Marx’ın dile getirdiği gibi: “(...) gözün insan gözü haline gelmesi, ancak toplumsal, insansal bir nesnenin -insan için insan tarafindan yapılan bir nesnenin- gözün nesnesi haline gelmesiyle olmuştur. Bu nedenle, duyular, doğrudan doğruya pratik işlevleriyle, birer kuramcı haline gelmişlerdir... Beş duyunun oluşması, bugüne kadar gelen dünya tarihinin bir ürünüdür', ${ }^{75}$

Son olarak tasarım kelimesinin fenomenlerinden bağımsız kullanımının yalnızca bir belirsizliğe işaret ettiği; ancak kavram, varlık, ürün, etkinlik gibi bir fenomenle yan yana getirilerek kullanımının anlamlı olabileceği söylenmelidir.

\section{KAYNAKCุA}

Albert Bayet, Bilim Ahlakı, çev. Vedat Günyol, (İstanbul: Çan Yayınları 1963).

Aydın Çubukçu, Teoride ve Eylemde Diyalektik Materyalizm, (İstanbul: Evrensel Basım Yayın 2008).

Bülent Yılmaz, Bilgi Toplumu: Eleştirel Bir Yaklaşım, (Ankara: Hacettepe Üniversitesi Edebiyat Fakültesi Dergisi).

75 Marx ve Engels, Sanat ve Edebiyat, çev. Murat Belge, (İstanbul: De Yayınevi 1971), s. 43. 


\section{Devrim BARAN}

Boguslavsky/Karpuşin/Ratikov/Çertikin/Ezrin, Diyalektik ve Tarihsel Materyalizmin Alfabesi, (Ankara: Bilim ve Sosyalizm Yayınları 1990).

Deniz Adalı, Diyalektik Materyalizm Tarihsel Materyalizm, (İstanbul: Kaldıraç Yayınevi 2011).

Friedrich Engels, Doğanın Diyalektiği, çev. Arif Gelen, (Ankara: Sol Yayınları 1977).

Georges Politzer, Felsefenin Temel İlkeleri, çev. F. Karagözlü, (İstanbul: Sosyal Yayınları 1977).

Gordon Childe, Kendini Yaratan İnsan, çev. Filiz Ofluoğlu, (İstanbul: Varlık Yayınları 1996).

Üsküdar University Journal of Social Sciences Year:2 Issue:3
Haluk Geray, İletişim, Bilgi Toplumu ve Küreselleşme, Emperyalizmin Yeni Masalı: Küreselleşme içinde, der. Işık Kansu, (Ankara: İmge Yayınları 1997). İrfan Erdoğan, Pozitivist Metodoloji ve Ötesi, (Ankara: Erk Yayınları 2012). İsmail Tunalı, Tasarım Felsefesine Giriş, (İstanbul: Yapı Endüstri Merkezi Yayınlar1 2002).

Jacques Ranciere, Görüntülerin Yazgısı, çev. Aziz Ufuk Kılıç, (İstanbul: Versus Yayınları 2008).

J.C. Scott, Tahakküm ve Direniş Sanatları, çev. Alev Türker, (İstanbul: Ayrıntı Yayınları 1995).

J. D. Bernal, Materyalist Bilimler Tarihi, çev. Emre Marlal1, cilt 1, (İstanbul: Sosyal Yayınları 1976).

John Heskett, Tasarım, (Ankara: Dost Yayınları 2013). 
Tasarımın Diyalektiği: Diyalektik Kavrayıșla Tasarım Kavramına Dokunma Denemesi

Josef Stalin, Diyalektik Materyalizm ve Tarihsel Materyalizm, çev. Zeynep Seyhan, (Ankara: Bilim ve Sosyalizm Yayınları 1989).

J. Stalin, Leninizmin Ilkeleri, çev. M. Kabagil, (Ankara: Sol Yayınları 1969).

J.V. Stalin, Anarşizm mi Sosyalizm mi? çev. İsmail Yarkın, (İstanbul: İnter Yayınlar1 1997).

M. Rosenthal, P. Yudin, Materyalist Felsefe Sözlüğ̈̈, çev. Aziz Çalışlar, (İstanbul: Sosyal Yayınları 1972).

Karl Marx, Kapital, Birinci Cilt, çev. Alaattin Bilgili, (Ankara: Sol Yayınları 2004).

-----------, Grundrisse, çev. Sevan Nişanyan, (İstanbul: Birikim Yayınları 1979).

------------, Felsefe Incelemeleri, çev. Cem Eroğlu, (Ankara: Sol Yayınları 1968).

------------, Alman İdeolojisi [Feuerbach], çev. Sevim Belli, (Ankara: Sol Yayınları 2010).

-----------, Sanat ve Edebiyat, çev. Murat Belge, (İstanbul: De Yayınevi 1971).

Karl Marx ve Friedrich Engels, Komünist Manifesto, çev. Etem Levent Bakaç, (İstanbul: Zeplin 2015).

Lev Troçki, Gündelik Hayatın Sorunları, çev. Yılmaz Öner, (İstanbul: Yazın Yayıncılık 2000).

Madan Sarup, Post-Yapısalcılık ve Postmodernizm, çev. Abdülbaki Güçlü, (İstanbul: Bilim ve Sanat Yayınları 2004). 


\section{Devrim BARAN}

Malcolm Barnard, Sanat, Tasarım ve Görsel Kültür, (Ankara: Ütopya Yayınları 2002).

Manfred Buhr, Alfred Kosing, Bilimsel Felsefe Sözlüğü, çev. Veysi Bildik, (İstanbul: Konuk Yayınları 1999).

Mao Tse-Tung, Çin İnkılâbının Teorik Meseleleri, çev. K. Sahir Sel, (İstanbul: Sosyal Yayınları 1966).

Maurice Bouvier-Ajam, Jean İbarrola, Nicolas Pasquarelli, Marksist Ekonomi Sözlügü̈, çev. B. Aren, İ. Yaşar, (İstanbul: Sosyal Yayınları 1977).

Mehmet İnanç Turan, Marx’ın Grundrisse’si, (Ankara: Ütopya Yayınevi 2015).

Üsküdar University Journal of Social Sciences

Year:2

Issue:3

Mehtap Yeşilorman, Firdevs Koç, Bilgi Toplumunun Teknolojik Temelleri Üzerine Eleştirel Bir Bakış, (Elazı̆̆: Fırat Üniversitesi Sosyal Bilimler Dergisi 2014).

Mustafa Kınık, Grafik Tasarım ve Üretim Teknolojileri, (Ankara: Asil Yayınc1lik 2005).

Münir Ramazan Aktolga, Bilimsel Teknolojik Devrim ve Diyalektik, (İstanbul: Ulusal Kültür Yayınları 1991).

Nazife Güngör, İletişim, Kuramlar-Yaklaşımlar, (Ankara: Siyasal Kitabevi 2011).

Nigan Bayazıt, Tasarımı Anlamak, (İstanbul: İdeal Kültür Yayıncılık 2008).

Oğuz Bayrakçı, Çağdaş İletişim Kuramları Açısından Tasarımda İletişimsel Modeller, (İstanbul: Mimar Sinan Güzel Sanatlar Üniversitesi Yayınları 2004). 
Tasarımın Diyalektiği: Diyalektik Kavrayıșla Tasarım Kavramına Dokunma Denemesi

Oscar Wilde, Sosyalizm ve İnsan Ruhu, (İstanbul: Re Yayınları 2006).

Slavoj Zizek, Yamuk Bakmak, çev. Tuncay Birkan, (İstanbul: Metis Yayınları 2012).

Yılmaz Öner, Bilimlerde ve Sanatta Diyalektik, (İstanbul: Belge Yayınları 1990). 